\title{
Out of Bounds: A Critical Race Theory Perspective on 'Pay for Play'
}

\section{Kevin Brown and Antonio Williams*}

\begin{abstract}
Under the amateur/education model, the amount of funding that colleges and universities can provide to their student-athletes is limited to the athletes' cost of attending their institution. This model makes sense for most college sports, but National Collegiate Athletic Association ("NCAA") Division I Football Bowl Subdivision and Division I men's basketball tend to generate almost all the revenue to fund their institution's entire athletic programs - as well as a substantial percentage of the revenues received by the NCAA. Furthermore is the realization that a majority of the elite athletes in these two revenue-generating sports are black. As revenues generated by these sports have escalated, a contentious debate has raged for more than 30 years about the potential racial exploitation of the application of the amateur/education model to these two sports. Both sides of this debate tend to perceive the issue of racial exploitation in terms of dividing the revenues between the athletes or the NCAA and its member institutions. Institutions either receive more of the funds to use as they see fit, or more revenues are provided to the athletes - probably at the expense of the amateur/education model. This article seeks to reformulate this debate by concentrating on the interests of the entire Black Community, not just those of elite black male athletes. By examining the Black Community's perspective, potential solutions to the enduring dilemma of racial exploitation emerge. To counteract the charge that the amateur/education model is potentially racially exploitive, the NCAA and its member institutions might institute and fund massive programs that increase college attendance and graduation rates for the entire Black Community. Admittedly, these programs would necessarily be tailored in a manner that does not run afoul of the current interpretations of antidiscrimination laws, but that is possible.
\end{abstract}

\footnotetext{
* Kevin Brown, JD, is the Richard S. Melvin Professor of Law at Indiana University; brownkd@, indiana.edu. Antonio Williams, $\mathrm{PhD}$, is an associate professor in the School of Public Health at Indiana University.
} 


\section{Introduction}

Historically, what defined college sports were the twin principles of its identification with academic traditions and amateurism. ${ }^{1}$ In other words, the conventional view of the National Collegiate Athletic Association ("NCAA") and its member institutions is that athletic programs are a vital part of an institution's educational mission and their athletes are essential members of their student body. Further, amateurism holds that college athletes should not receive compensation beyond expenses related to attending college to play their sport. As the NCAA Constitution puts it, the participation of student-athletes:

Should be motivated primarily by education and by the physical, mental and social benefits to be derived. Student participation in intercollegiate athletics is an avocation, and student-athletes should be protected from exploitation by professional and commercial enterprises. ${ }^{2}$

Professor Timothy Davis terms this view of college athletic programs the "amateur/education model." 3 It is here where the NCAA rules find their significance. Indeed, the primary purpose of the NCAA's labyrinthine rules is to ensure that competition on the field is done on fair terms that are consistent with its member institutions' shared commitment that athletes are both students and amateurs.

If college sports is considered from the viewpoint of more than 460,000 student-athletes competing in the three divisions of the NCAA, then the amateur/education model makes sense. ${ }^{4}$ Since almost all of these athletes play in competitions that generate little or no revenue for their academic institutions, the primary beneficiaries of the competition are the participants. This reality is also reflected in the fact that only about 20 of the Division I athletic departments report a surplus when their entire athletic budgets are considered. ${ }^{5}$ However,

\footnotetext{
1 The NCAA's Principle of Amateurism states: "Student-athletes shall be amateurs in an intercollegiate sport, and their participation should be motivated primarily by education and by the physical, mental and social benefits to be derived. Student participation in intercollegiate athletics is an avocation, and student-athletes should be protected from exploitation by professional and commercial enterprises." NCAA CONST. ART. 2.9.

2 NCAA Const. ARt. 2.9; see also 2015-16 NCAA Division 1 Manual 3 (2015), http://www.ncaapublications.com/productdownloads/D116.pdf.

3 Timothy Davis, Intercollegiate Athletics: Competing Models and Conflicting Realities, 25 Rutgers L.J. 269, 270 (1994).

4 Student Athletes, NCAA, http://www.ncaa.org/student-athletes (last visited Feb. 2, 2018).

5 The NCAA defines operating surplus in its biannual Revenues and Expenditures report to refer to generated revenues (including donations) minus operating costs, where operating costs exclude most capital expenses. See Daniel L. Fulks, Revenues \& Expenses: 2004-2014 NCAA Division I Intercollegiate Athletics Programs Report 11, 24 (2015), https:/www.ncaa.org/sites/default/ files $/ 2015 \% 20$ Division $\% 20 I \% 20$ RE\%20report.pdf [hereinafter NCAA, Revenues and Expenses 2015]. Based on these calculations, the NCAA noted, "A total of 24 athletics programs in the FBS reported positive net revenues for the 2014 fiscal year." Id. at 8 .
} 
separate from the participatory sports are those that generate huge revenues from the viewing public. Although there are variations at some educational institutions, the primary revenue-generating college sports are NCAA Division I Football Bowl Subdivision (FBS football) and Division I men's basketball (men's basketball). ${ }^{6}$ For example, during the fiscal year of July 1, 2016, to June 30, 2017, at Indiana University-Bloomington, the men's basketball and football teams generated $98.2 \%$ of the allocated revenue from all sports teams. ${ }^{7}$ The net allocated revenue from football was $\$ 11,412,804$ and men's basketball was $\$ 11,705,810$. $^{8}$ All other sports combined reported a loss of $\$ 21,090,498 .^{9}$ For colleges and universities that field FBS football and men's basketball teams, the net profit from these two sports provides a substantial portion of the athletic-related revenue that is used to cover the expenses of all the other sports programs. ${ }^{10}$ In other words, in addition to funding the expenses of the athletes in the revenue sports, the funds they generate pay for escalating coaching salaries in revenue sports, scholarships for non-revenue athletes, coaching expenses for non-revenue sports, increased costs of athletic department staff members, updated athletic facilities for all sports teams, luxury boxes at football and basketball stadiums for alumni, donors, and dignitaries, and subsidizing university budgets. ${ }^{11}$ Men's basketball is also the primary source for the revenue received by the NCAA. It owns the marketing rights for the NCAA men's basketball tournament, from which the

\footnotetext{
6 Although other sports generate significant revenues for certain colleges and universities, the two college sports that typically generate the largest revenues are FBS football and Division I men's basketball. Throughout this article, mention of revenue sports refers only to these two sports.
}

7 Total allocated revenue was $\$ 63,524,353$ of which $\$ 24,560,829$ came from men's basketball and $\$ 37,085,787$ from football. U.S. DEPT. of EduCATION, Indiana University-Bloomington, EQUITY In Athletics Data Analysis, https:/ope.ed.gov/athletics/\#/institution/details (last visited Feb. 4, 2018).

8 For basketball the net income was $\$ 11,705,810(\$ 24,560,829-\$ 12,855,019)$ and for football it was $\$ 11,412,804$ (\$37,085,787-\$25,672,983). Id.

9 For sports other than men's basketball and football, the total allocated net loss was $\$ 21,873,304$ $(\$ 1,616,235-\$ 23,489,539)$. Id. Thus, it could be asserted that the net profits from men's basketball and football were used to provide the funds for all of the expenses of the other sports programs at Indiana University.

10 For example, in fiscal year 2010, the FBS football programs earned a median of \$3.1 million more than revenue for the team. Division I men's basketball teams produced a median profit of $\$ 788,000$. But the medians for all other sports were net losses. See, e.g., Ahmed E. Taha, Are College Athletes Economically Exploited? 2 Wake Forest J. L. \& PoL'y 69, 72 (2012); see also Knight Commission on Intercollegiate Athletics, College Sports 101, Chapter 3: Revenue (2009), http://www.knightcommission.org/collegesports101/chapter-3.

11 For instance, a 2015 press release announcing the dedication of Indiana University-Bloomington's new Global and International Studies Building stated that the "new \$53 million building was funded entirely through university sources with half of the funding coming from IU's Big Ten Network revenues, representing the largest-ever commitment from IU Athletics revenue to support the core academic mission of the university." Press Release, IU to Dedicate Its New Global and International Studies Building, IU NEwsRoom, http://archive.news.indiana.edu/releases/

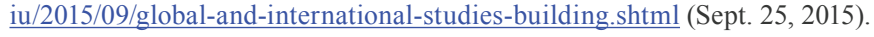


NCAA derives a substantial percentage of its operating funds. In fiscal year 2014, for example, the NCAA's total revenues exceeded \$1 billion with the majority of those revenues, about $\$ 700$ million, coming from television and marketing agreements with CBS and Turner Broadcasting for the NCAA Tournament. ${ }^{12}$

Viewing the amateur/education model from the perspective of all athletes playing at NCAA member institutions certainly makes sense. However, whether the model (specifically the principal of amateurism) should apply to the athletes in revenue sports is a different matter. Similarly, civil rights historian Taylor Branch noted that the sentiment of amateurism "blinds us to what's before our eyes. Big-time college sports are fully commercialized. Billions of dollars flow through them each year. The NCAA makes money, and enables universities and corporations to make money, from the unpaid labor of young athletes." 13 This issue also resided at the heart of the recent decision in March 2019 in Alston $v$. $N C A A$ by federal district court judge Claudia Wilken of the Northern District of California. While allowing for the NCAA to continue the current limits on athletic scholarships, Judge Wilkens enjoined the NCAA from limiting most compensation and benefits that are related to education including computers, science equipment, musical instruments, and other items not currently included in the cost of attendance calculation but nonetheless related to the pursuit of various academic studies. Also included would be post-eligibility scholarships to complete undergraduate or graduate degrees at any school; scholarships to attend vocational school; expenses for pre- and post-eligibility tutoring; expenses related to studying abroad that are not covered by the cost of attendance; and paid post-eligibility internships. ${ }^{14}$

Judge Wilkens did allow the NCAA to limit a subset of education-related benefits such as cash academic or graduation awards and incentives that could potentially become unlimited and allow for payments indistinguishable from those received in professional sports.

Added to these circumstances is the realization that the majority of the elite athletes in revenue sports are black. Notably, in 2017, 44.2\% of Division I football players were black, but the percentage was higher at FBS schools, 55.9\% ${ }^{15}$ As for men's basketball, black men made up $53.0 \%$ of the players. ${ }^{16}$ In regards to the Power Five Conferences - the Atlantic Coast Conference ("ACC"), Big Ten Conference, Big 12 Conference, Pac 12 Conference, and the Southeastern Conference ("SEC") — black males constituted only $2.5 \%$ of the undergraduate

\footnotetext{
12 Steve Berkowitz, NCAA Nearly Topped \$1 Billion in Revenue in 2014, USA TodAy (Mar. 11, 2015), http://www.usatoday.com/story/sports/college/2015/03/11/ncaa-financial-state$\underline{\text { ment-2014-1-billion-revenue/70161386/ }}$

13 Taylor Branch, The Shame of College Sports, The Atlantic Magazine 80-103 (2011).

${ }^{14}$ In Re: National Collegiate Athletic Association Athletic Grant-In-Aid Cap Antitrust Litigation v. NCAA, 375 F. Supp. 3d 1058, 1088 (N.D. Cal. 2019).

15 Richard Lapchick et al., Univ. Cent. Of Fla. Inst. for Diversity and Ethics in Sport, The 2017 Racial And Gender Report Card: College Sport 5 (2017), http://nebula.wsimg.com/5665825afd75728dc0c45b52ae6c412d?AccessKeyId=DAC3A56D8FB782449D2A\&disposition=0\&alloworigin $=1$. 
students at these institutions, but they made up a much higher percentages of the athletes in revenue sports, $56.3 \%$ of football players and $60.8 \%$ of the men's basketball players. ${ }^{17}$ As a result of this substantial over-representation of black male athletes, critics often raise a potential charge that the application of the amateur/education model to revenue sports is imbued with racial exploitation. ${ }^{18}$ As ESPN reporter Kevin Blackstone put it, "One could clearly envision Black men as gerbils on a wheel that produce the financial energy for all intercollegiate sports to survive and prosper." 19 More candidly, former legendary Louisiana State University ("LSU") basketball coach Dale Brown stated, "Look at the money we make off predominantly poor black kids, we're the whoremasters." ${ }^{20}$ This criticism, unfortunately, is not new. It has been leveled at college sports for more than three decades. One example is a 1986 article in the New Republic titled, "Dunk and Flunk," where Malcolm Gladwell discussed the politics of race on university campuses. Another is professor Gary Sailes's 1986 article titled, "The Exploitation of the Black Athlete: Some Alternative Solutions."21

According to a 2014 Marist Poll, however, many Americans don't believe that race has anything to do with the fact that top college athletes in football and basketball are not paid. ${ }^{22}$ The results of the poll showed that $17 \%$ indicated that they saw no or very little legitimacy to the claim, while an additional $53 \%$ called the assertion false. However, as anyone knowledgeable about the U.S. racial scene might expect, there were significant differences based on the race of the respondents. More than $60 \%$ of blacks, but only a third of Latinos and a quarter of whites, believed that top college athletes are unpaid because many of these

\footnotetext{
17 Shaun Harper, Univ. of Pa. Center for the Study of Race and Equity in Education, Black Male Student-Athletes and Racial Inequities in NCAA Division I College Sports 2016 Edition 1 (2016), https://equity.gse.upenn.edu/sites/default/files/publications/Harper_Sports_2016.pdf.

18 See, e.g., Emma Kerr, The NCAA as Modern Jim Crow? A Sports Historian Explains Why She Drew the Parallel, The Chronical of Higher Education (Jan. 12, 2018), https://www.chronicle. com/article/The-NCAA-as-Modern-Jim-Crow-A/242240?cid=wb\&utm source=wb\&utm_medium $=$ en\&elqTrackId $=6103 \mathrm{a} 75 \mathrm{a} 8 \mathrm{c} 28482 \mathrm{dbc6c8e} 89 \mathrm{af0171a0 \& elq=}$ b2f5156d29a34204b0dac-

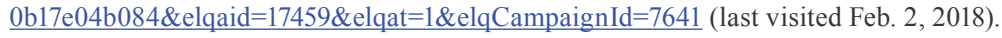

19 HARPER, supra note 18 , at 2.

20 Branch, supra note 15.

21 See, e.g, Norton, No Time for Classes, 4 Calif. Law 42, 46 (1984); Malcolm Gladwell, Dunk and Flunk, 194 New Republic 13-15 (1986); Gary Sailes, The Exploitation of the Black Athlete: Some Alternative Solutions, 55 J. NEGRO EDUC. 439 (1986); see also Erik Jensen, Taxation, the Student Athlete, and the Professionalization of College Athletics, 1987 UtaH L. Rev. 35 (1987).

22 Race Impacts Decision Not to Pay College Athletes, Say More than Three in Ten, MARIst Poll (Mar. 25, 2014), http://maristpoll.marist.edu/326-race-impacts-decision-not-to-pay-collegeathletes-say-more-than-three-in-ten/\#sthash.WiVnkL81.dpbs. For a copy of the poll results, see http://maristpoll.marist.edu/wp-content/misc/usapolls/us140203/Sports/Complete $\% 20 \mathrm{March} \% 20$ 2014\%20USA $\% 20 \mathrm{HBO} \% 20$ Real $\% 20$ Sports Marist $\% 20$ Poll $\% 20$ Tables.pdf\#page=3; similar results were also found in a Washington Post/ABC News Poll in 2014, see Alex Prewitt, Large majority opposes paying NCAA athletes, Washington Post-ABC News poll finds, WASH. Post (Mar. 14, 2014), https://www.washingtonpost.com/sports/colleges/large-majority-opposes-paying-ncaaathletes-washington-post-abc-news-poll-finds/2014/03/22/c411a32e-b130-11e3-95e8-39bef8e9a48b_story.html?noredirect $=$ on\&utm term $=. e 1503 \mathrm{a} 9 \mathrm{~d} 5550$.
} 
athletes are black. ${ }^{23}$ In addition, $53 \%$ of blacks but only $25 \%$ of whites believe that these athletes should be paid for their time spent practicing, training, and playing. ${ }^{24}$ The Washington Post reported results of a different poll in September of 2017, which found that half of U.S. sports fans felt that a scholarship was adequate compensation for college football and basketball players, with $41 \%$ believing they should be paid more. ${ }^{25}$ But, like the Marist Poll, there were substantial racial divides, with $54 \%$ of blacks as opposed to $31 \%$ of whites and $41 \%$ of Hispanics believing the players should be paid. ${ }^{26}$

When those who believe in the amateur/education model face the issue of whether the current system is racially exploitive, they must relate any shortcomings in the current system to the failure of institutions to provide the athletes with enough resources in order to have a realistic opportunity to obtain a valuable four-year degree. For these believers, if there are any deficiencies in the current compensation system, the solutions relate to colleges and universities doing more to assure that their athletes graduate with meaningful degrees. But it is important to note that the NCAA and its member institutions have taken several significant steps over the past 35 years to increase the percentages of athletes graduating with meaningful degrees. These measures have substantially improved graduation rates of all athletes, particularly black male athletes in revenue sports.

Additionally, either on its own initiative or as a result of the threat of antitrust litigation, ${ }^{27}$ the NCAA has repealed regulations that both limited athletic scholarships to one-year renewable at the option of the institution and limited the amount of the scholarships to amounts necessary to cover only tuition and fees, room and board, and required course-related books (collectively known

\footnotetext{
23 MARist Poll, supra note 23.

24 Marist Poll, supra note 23.

25 Pamela MacLean and Eben Novy-Williams, NCAA, Athletes Draw Questions from Judge
} Over Pay for Play, Bloomberg (Jan. 16, 2018, 7:57 PM), https://www.bloomberg.com/news/articles/2018-01-17/ncaa-athletes-draw-questions-from-judge-over-pay-for-play.

26 Will Hobson and Emily Guskin, Poll: Majority of Black Americans Favor Paying College Athletes; 6 in 10 Whites Disagree, WAsh. Post (Sept.14, 2017), https:/www.washingtonpost.com/ sports/colleges/poll-majority-of-black-americans-favor-paying-college-athletes-6-in-10-whitesdisagree/2017/09/14/27fa5fc2-98df-11e7-87fc-c3f7ee4035c9 story.html?noredirect=on\&utm ter$\underline{\mathrm{m}=.1251 \mathrm{cc} 1048 \mathrm{e} 0}$.

27 O'Bannon v. NCAA, 7 F. Supp. 3d 955, 971 (N.D. Cal. 2014) rev. O’Bannon v. NCAA, 802 F.3d 1049 (9th Cir., 2015) cert. den. 137 S. Ct. 277 (2016). In this case, the District Court enjoined the NCAA from limiting scholarships to grant-in-aid amounts for FBS football and men's basketball scholarship athletes. Separate cases were originally filed former University of Nebraska quarterback Sam Keller and former UCLA basketball player Ed O'Bannon and merged into a single class action lawsuit against the NCAA. The O'Bannon case began as an effort challenge the NCAA and its member institutions rules that prevented athletes from receiving a share of the sale of licenses to use the student athletes' names, images, and likenesses in videogames, live game telecasts, and other footage. O'Bannon and 19 others filed a class action antitrust lawsuit against the NCAA, arguing that the NCAA was wrongfully profiting from the sale of players' images and likenesses in the EA Sports video games without providing the athletes any compensation. The NCAA countered by arguing that to provide such compensation to the athletes would violate the principal of amateurism. 
as "grant-in-aid" amounts). Member institutions can now offer multi-year full "cost-of-attendance" scholarships, ones that cover grant-in-aid amounts plus miscellaneous expenses incurred when attending college such as laundry, entertainment, and trips back and forth to home. Thus, under NCAA regulations currently in place, Division I colleges and universities are free to offer their athletes multi-year scholarships and ones that include an additional amount beyond grant-in-aid figures to cover the miscellaneous expenses of attending college, usually between $\$ 3,000$ to $\$ 7,000$.

Proponents of the amateur/education model applied to revenue sports must reckon with the reality that conditions for athletes, both academically and financially, have significantly improved. There is also the possibility that there will come a time when colleges and universities reach the extent of their abilities to ensure that their athletes have a realistic opportunity to receive a legitimate four-year college degree. Nonetheless, the revenues generated by FBS football and men's basketball are likely to continue to increase. For example, in 2012, ESPN paid \$5.64 billion for the broadcasting rights for the first College Football Playoffs. ${ }^{28}$ The Knight Commission reported that the combined revenue for the Power Five conferences increased by $266 \%$ from $2005-15 .{ }^{29}$ In 2010 , the NCAA signed an \$11 billion, 14-year agreement for the television rights for the NCAA men's basketball tournament. This was a $41 \%$ increase over its prior deal. The NCAA also reached an agreement for an eight-year extension in 2016 with CBS and Turner in which the NCAA will receive an additional $\$ 8.8$ billion. ${ }^{30}$ Moreover, in the near future college sports may be able to take advantage of new revenue streams from Internet platforms like Google and Amazon. ${ }^{31}$ Consequently, those who find that the amateur/education model is not racially exploitive must contend with whether they will maintain that view in 10 or 20 years when funds from these sports continue to escalate and simultaneously there is little or no room for improving academic achievement of black male athletes in revenue sports.

On the other hand, some believe the amateur/education model does not allow athletes to receive enough compensation for their services. From this view, the NCAA and its member institutions should provide or allow student-athletes to receive more funds. Based on her decision in Alston v. NCAA, Judge Wilkens clearly sympathizes with these individuals, but her opinion accepted the NCAA argument that unlimited compensation for student-athletes unconnected to educational expenses is valid.

Even if it were possible, any college or university that decides to pay its revenue-sports athletes beyond the cost-of-attendance scholarships must consider

\footnotetext{
28 Rachel Bachman, ESPN Strikes Deal for College Football Playoff, Wall Street J. (Nov. 21, 2012), http://www.wsj.com/articles/SB10001424127887324851704578133223970790516.

29 John Solomon, The History Behind the Debate Over Paying NCAA Athletes, AsPEn Ins. (Apr. 23, 2018), https://www.aspeninstitute.org/blog-posts/history-behind-debate-paying-ncaa-athletes/.

30 Rodger Sherman, The NCAA's New March Madness TV Deal Will Make Them a Billion Dollars a Year, SB NATION (Apr. 12, 2016), https://www.sbnation.com/college-basketball/2016/4/12/11415764/ncaa-tournament-tv-broadcast-rights-money-payout-cbs-turner.

31 Andy Staples, With Upheaval in Cable Market, Power 5 Bet on Silicon Valley to Keep Rights Revenue Flowing, SPORTs Illustrated (May 8, 2017), https://www.si.com/college-football/2017/05/08/power-five-tv-rights-deals-amazon-google (last visited Feb. 3, 2018).
} 
several potential legal obstacles. To begin with, under the broad tax exemption provided by Internal Revenue Code ("IRC") Section 501(c)(3), income generated by revenue sports is exempt from taxation for colleges and universities because it is treated as "substantially related" to a university's educational mission. ${ }^{32}$ If educational institutions pay student-athletes in revenue sports, there is a stronger argument that income generated by these "employees" is unrelated to the institution's educational mission. If it is, that income would become subject to federal income taxes. For a number of other legal purposes, paying athletes also runs the risk that students become employees. Such a determination carries with it various concerns, including the following: federal income taxes, state income taxes, social security and Medicare contributions by both the athletes and their institutions, unemployment taxes, increased tort liability for colleges and universities through the application of respondeat superior, and increased constitutional due process protections for athletes at public colleges and universities. Educational institutions must additionally comply with Title IX, which requires equal treatment of the male and female athletes.

Beyond the aforementioned noted legal considerations are the practical considerations of how to equitably compensate players? After all, shouldn't the starting quarterback receive more than the third-string left guard? Or shouldn't the leading basketball scorer receive more than the reserve defensive specialist? Admittedly, there is less competitive balance in college sports than most sports fans would like. For instance, as recently pointed out by Purdue University president Mitch Daniels, in the five years leading up to the 2017-2018 season, 45\% of the "five-star" basketball recruits, and $58 \%$ of those who played for one year before turning pro, have gone to just five schools. ${ }^{33}$ It has also become commonplace to cheer against the University of Alabama (maybe now Clemson) winning another FBS football championship. But, the question remains, what happens to the competitive balance that still exists in these college sports if the athletes are paid to play? As previously noted, only about 20 athletic departments currently generate more revenue than expenses. Therefore, the funds to pay athletes in revenue sports is likely to reduce the ability of colleges and universities to maintain non-revenue sports. Accordingly, proponents of the amateur/education model must further reckon with the possibility that implementation of their approach could lead to the dissolution of college sports as we know it. ${ }^{34}$

Both sides of the debate regarding whether the amateur/education model applied to revenue sports is racially exploitive tend to follow the same path of discussion that commentators have employed for 30 years. They view the issue in terms of dividing the revenues between the athletes or the NCAA and its member institutions. Either the institutions receive more of the funds to use as they see fit

\footnotetext{
32 I.R.C. $\$ 501(\mathrm{c})(3)$.

33 Mitch Daniels, Daniels: Good Luck Fixing the Cesspool that is the NCAA, Condoleezza Rice, InDY STAR (Feb. 2, 2018), https://www.indystar.com/story/opinion/2018/02/02/daniels-good-luckfixing-cesspool-ncaa-condoleezza-rice/302446002/.

34 But see Jeffrey Standen, The Next Labor Market in Sports, 92 Or. L. REv. 1093 (2014) (arguing we would not notice much of a change if some colleges and universities started to pay players for their services).
} 
or more of the revenues are provided to the athletes - probably at the expense of the amateur/education model.

Raising the question about the possibility of the amateur/education model applied to revenue sports being racially exploitive first requires an understanding of the concept of race discrimination. The predominant legal definition of racial discrimination requires that for it to exist, discriminatory intent must motivate the actor's conduct. To prove discriminatory intent, more is required than an awareness of the racial consequences of an otherwise neutral policy. The relevant decision maker must adopt the policy at issue because of - not merely in spite of - its adverse effects on an identifiable racial group. ${ }^{35}$ This is the definition of racial discrimination contained in the equal protection clause of the Fourteenth Amendment, which applies to public colleges and universities because they are governmental entities. It is also the definition used in lawsuits derived from Title VI of the Civil Rights Act of 1964 that applies to all colleges and universities because they receive federal funds. It is, moreover, the definition of race discrimination under Section 1981, which applies to the NCAA and all of its member institutions. The reality that the NCAA and its member institutions are aware of the fact that black male athletes are generating the revenue that is benefitting so many others is largely irrelevant, from the point of view of this definition of racial discrimination. Few, if any, commentators would seriously contend that the NCAA and its member institutions embrace the application of the amateur/ education model to revenue sports not in spite of, but because it disadvantages black male athletes.

Beyond the predominant legal definition of racial discrimination, another concept of racial exploitation is centered on a concept of race discrimination not in terms of the motives of an actor, but the effects of the actor's conduct. These negative effects may result in part from discriminatory intent, but they may also result from unconscious racism, the use of stereotypes, or institutional racism - specifically formal or informal structural mechanisms such as policies and programs that work to systematically produce disproportionately negative consequences on under-resourced minorities. It is from this latter viewpointdiscriminatory effects - that issues about the racially exploitive nature of the amateur/education model applied to revenue sports makes the most sense.

If the question regarding limits on compensation to FBS football and men's basketball players is viewed from the point of view of its discriminatory effect, then the concern should be about the impact on the entire Black Community, not just elite black male athletes. This understanding allows us to recognize that the issue of compensation of athletes in revenue sports is not limited to the NCAA and its member institutions on one hand, and the athletes, on the other. But, the Black Community has a separate interest at stake. By taking the perspective of

\footnotetext{
35 Pers. Adm'r of Mass. v. Freeney, 442 US 256, 279 (1979). The Supreme Court has approved the interpretation of the implementing regulations for Title VI of the 1964 Civil Rights Act that declared discrimination is barred "which has that effect even though no purposeful design is present," citing Lau v. Nichols, 414 US 563, 568 (1974). However, in Alexander v. Sandoval, 532 US 275 (2001), the Court concluded that there is no private right of action under the implementing regulations of Title VI.
} 
the entire Black Community, instead of the prevailing perspective limited to that of elite black male athletes, a different view of the issue of racial exploitation and, more importantly, potential solutions to combat the exploitation that is embedded in the amateur/education model emerge.

If we see the issue of racial exploitation in terms of the entire Black Community, then potential solutions are not limited to simply deciding how to split the funds produced by the revenue sports between the institutions or the athletes. To counteract the charge that the amateur/education model is potentially racially exploitive, the NCAA and its member institutions could institute and fund massive programs that would help to increase the college attendance and graduation rates for the entire Black Community. To lessen the financial blow, those funds could come from increases in revenue. The programs could not only assist blacks that are currently on the campuses of Division I schools, but also help junior high and high school students in predominately black school districts throughout the country enroll in colleges and universities after high school. Admittedly, these programs would have to be tailored in such a way as not to run afoul of the current interpretations of anti-discrimination laws, but that is possible. ${ }^{36} \mathrm{We}$ must also trust that college and university administrators will not simply reallocate athletic revenue and use it to replace funds currently spent on diversity programs.

The focus on this article is, therefore, on the issue of the potential racial exploitation that exists when the amateur/education model is applied to revenue sports. But it addresses this issue from the perspective of the Black Community and focusing on ways to re-envision the role of race in college sports.

College sports have not always been a major commercial activity. In 1984, the Supreme Court rendered its only antitrust opinion involving college sports. Applying antitrust law, in NCAA v. Board of Regents, ${ }^{37}$ the Court ended the 33year reign of the NCAA over the television rights to college football games of its member institutions. At the same time, however, the Court accepted the amateur/ education model set forth by the NCAA as the basis of college sports for antitrust purposes. By deregulating the control of the NCAA over member institutions' television rights, the Court paved the way for substantial increases in revenues generated by college sports, while it also limited the amounts college athletes could receive. Section II of this article will discuss this Court opinion as well as the rise of the business of college sports that the deregulation of broadcasting rights helped to make possible. Given the limits placed on compensation for the athletes, this savings has generated additional funds for an arms race involving rapidly rising salaries for the best head coaches of revenue sports, extra funds for athletic departments, and more money for sports facilities. Section II will conclude by discussing this arms race.

\footnotetext{
36 See, e.g., Parents Involved in Cmty. Sch. v. Seattle Sch. Dist. No. 1, 127 S. Ct. 2738, 2792-3 (2007) (Kennedy, J., concurring in part and concurring in the judgment) (race conscious measures that do not employ individual racial classifications that further integrated schools do not trigger strict scrutiny).

37468 U.S. 85 (1984).
} 
Under the amateur/education model, the coaches of the football and basketball teams have every right to try to get as much out of a player as possible. But, in exchange, they should provide that player with every legitimate means necessary to obtain a meaningful college degree. Section III will discuss several policies and programs adopted and instituted by the NCAA and its member institutions over the past 35 years that have significantly improved the chances that member institutions will fulfill their part of the student-athlete/institution bargain. It will also discuss some of the major legal obstacles that exist to paying athletes to play beyond the cost of attending their institutions. As a result, substantial legal hurdles exist to abandoning the amateur/education model and paying athletes to play, even as the NCAA is running out of room within the model to improve the academic situation of the athletes competing in revenue sports.

Since this article is an attempt to conceptualize the debate regarding the potential racial exploitation that comes from applying the amateur/education model to the revenue sports, Section IV will look at the model from the perspective of the Black Community. It will point to the long history of racial subordination and the struggle against it that have produced a reality where the experiences of individual blacks are connected to those of the Black Community. It will then elucidate how revenue sports contribute to maintaining the most destructive negative stereotypes that blacks encounter in their daily lives, including a lack of intelligence and being prone to aggressive and violent behavior. Thus, the experiences of and generated by black athletes in revenue sports are connected to and influence the experiences of all those in the Black Community.

Finally, Section V will discuss a number of programs that the NCAA and its member institutions could consider that would advance the college attendance and graduation rates of the entire Black Community. This will help to counter the continuing charge that the amateur/education model applied to revenue sports is racially exploitive.

\section{NCAA v. Board of Regents: The Rise of the Business of College Sports}

Throughout the 1970s, the idea that college sports was not a separate commercial activity was deeply ingrained in higher education. This was a more innocent time for college sports. Seventh Circuit Federal Judge Flaum succinctly put it this way, this was "an era where recruiting scandals were virtually unknown, where amateurism was more a reality than an ideal, and where post-season bowl games were named for commodities, not corporations." 38 At this time, the compensation paid to college coaches fell in line with the overall university salary structure. For example, legendary UCLA basketball coach John Wooden's Bruins won 10 NCAA titles between 1964 and 1975. His last title came in his last year of coaching when UCLA paid him a salary of $\$ 40,000$ per year. ${ }^{39}$ The head basketball coach

\footnotetext{
38 See Banks v. NCAA, 977 F.2d 1081, 1099 (Flaum J., concurring in part and dissenting in part 7th Cir. 1992).

39 Matthew Sable, Pay to Play: College Athletes Deserve Compensation, The Pitt News (Mar.17, 2017), https://pittnews.com/article/117830/opinions/college-athletes-deserve-compensation/ (last visited Feb. 2, 2018).
} 
at Columbia University made the same as renowned Marquette basketball coach Al McGuire. ${ }^{40}$ Barry Switzer, who won national college football titles coaching the University of Oklahoma Sooners in 1974 and 1975, was making just $\$ 60,000$ as late as $1984 .^{41}$

Economist generally view the NCAA and its member institutions as a cartel maintaining the notion that athletes are amateurs and, thereby, limiting the compensation they have to pay. ${ }^{42}$ The NCAA has also been referred to as the best monopoly in the US. ${ }^{43}$ Thus, it is important to understand that the most likely legal avenue for significantly increasing the compensation paid to college athletes is by having courts strike down NCAA regulations as restraints on trade through antitrust litigation. Student-athletes who have challenged these restrictions on antitrust grounds have largely failed because courts have tended to uphold the NCAA's restrictions as justified because they provide two procompetitive benefits: (1) the preservation of amateurism in college sports, which increases consumer demand and (2) the integration of academics and athletics, which improves the college experience for student-athletes. This follows from the 1984 Supreme Court opinion that rendered its only antitrust decision impacting college sports, NCAA v. Board of Regents. In this opinion, the Court struck down the NCAA's 33-year control over college football televisions revenues. The deregulation of television rights that occurred in this decision paved the way for substantial increases in income generated by college sports. But the Court also accepted the NCAA's amateur/education model. As a result, for purposes of antitrust litigation, the decision enshrined the concept of amateurism as a necessary aspect of college sports and, thus, substantially limited the ability of antitrust law as a possible avenue in order to substantially increase revenues for college athletes.

The first section of this part will discuss how the opinion in NCAA v. Board of Regents paved the way for increased revenues derived from college sports while simultaneously limiting the compensation of athletes in revenue sports. It will also point to the substantial increases in revenues for college sports that has occurred since the Court's opinion. In order to determine whether athletes playing revenue sports are under-compensated, it is necessary to compare what they receive to the value of the services they render. The second section will address this comparison. Essentially, it will discuss the cost of a college education and present a number of different ways to value the financial contribution of the athletes playing in revenue sports to their institutions. Since the compensation that athletes in revenue sports receives is currently limited, one of the consequences is that there is more money to spend on coaches, athletic departments, and sports facilities. The last section will discuss the increasing amounts of compensation

\footnotetext{
40 John Akers, Golden Era of Coaching: From 'Lefty' to 'Bones': Yesteryear Coaches were Distinct Breed, NCAA (Mar. 29, 2012), http://www.ncaa.com/news/basketball-men/article/2012-03-26/golden-era-coaching.

${ }^{41}$ Jerry McConnell, Raises Due for Switzer, Tubbs, Daily OкцаномаN (Aug. 1, 1985), http://newsok.com/raises-due-for-switzer-tubbs/article/2116590/?page=1.

42 See, e.g., Daniel Sutter and Stephen Winkler, NCAA Scholarship Limits and Competitive Balance in College Football, J. SpORTS AND Econ. 3, 5 (2003).

43 Id.
} 
provided by member institutions to the head coaches of their revenue sports teams, augmented budgets for their athletic departments, and more funding for sports facilities.

\section{A. NCAA v. Board of Regents: Paving the Way for Increased Revenues While Limiting Athlete Compensation}

In 1984, the Supreme Court rendered its only opinion applying the Sherman Antitrust Act to college sports in NCAA v. Board of Regents. ${ }^{44}$ For the 33 years prior to the Court's decision, the NCAA, not individual schools or conferences, negotiated college football television contracts with the major television and cable networks. ${ }^{45}$ The NCAA imposed strict limits on television appearances of member institutions. It restricted the number of times a given school could appear on television, set a minimum number of schools that had to appear at least once, and determined a limit for the amount that each school would receive for its televised appearances. The Universities of Oklahoma and Georgia, however, challenged these NCAA restrictions under antitrust law as unreasonable restraints on trade and the Supreme Court agreed.

In rendering its opinion, the Court accepted the model of college sports put forward by the NCAA, which rests on the twin principals of the identification of it with an academic tradition and amateurism. ${ }^{46}$ In the opinion, the Court wrote:

[T] he NCAA seeks to market a particular brand of football-college football .... In order to preserve the character and quality of th [is] "product," athletes must not be paid, must be required to attend class, and the like. And the integrity of the "product" cannot be preserved except by mutual agreement; if an institution adopted such restrictions unilaterally, its effectiveness as a competitor on the playing field might soon be destroyed. Thus, the NCAA plays a vital role in enabling college football to preserve its character, and as a result enables a product to be marketed which might otherwise be unavailable. In performing this role, its actions widen consumer choice-not only the choices available to sports fans but also those available to athletes - and hence can be viewed as procompetitive" (emphasis added). ${ }^{47}$

For the Court preserving college sports, built on the twin principles of amateurism and connection to an academic institution, as something separate from professional sports like minor league baseball or the National Basketball

\footnotetext{
44468 U.S. 85 (1984).

45 The NCAA had not adopted any regulations to apply to televised athletic events, except for football games. Id. at 88-9. The NCAA never controlled television contracts for college basketball, except for its own NCAA basketball tournament.

46 Id. at 101.

47 Id. at 101-2.
} 
Association ("NBA") G League (formerly the NBA Development League) ${ }^{48}$ made sense from the perspective of an antitrust challenge because doing so provides both consumers and athletes with more options from which to choose to occupy their time, effort, and money.

In rendering its decision to eliminate the NCAA's control over television rights, the Court paved the way for dramatic increases in broadcasting and other revenues for colleges and universities with big-time sports programs. Simultaneously, in furtherance of the idea that college sports should be distinguished from professional sports, the Court allowed the NCAA and its member institutions to strictly limit the compensation of the athletes responsible for producing these increased revenues. In other words, the federal courts interpreted NCAA v. Board of Regents to foreclose the possibility that antitrust litigation would succeed in providing student-athletes in revenue sports a means to realize a substantial share of the increased revenues that started to flow to member institutions and the NCAA, in part, as a result of the Court's deregulation of televised broadcasting rights for college sports.

Since the Supreme Court's opinion in Board of Regents, college sports have become not just "big business," but a massive business industry. Collectively, the annual revenue from FBS football and men's basketball is over $\$ 7$ billion. ${ }^{4}{ }^{4}$ These revenues exceed those of the English Premier Soccer League, the NBA, and the National Hockey League ("NHL"). ${ }^{50}$ They make college sports the third most lucrative sports industry in the world behind only the National Football League ("NFL") and Major League Baseball ("MLB"). ${ }^{51}$ Technological advances in programing distribution, such as improved over-the-air television broadcasting, expansion of cable television systems, and creation of satellite and Internet broadcasting, have increased the ability of the viewing public to see college sports games and, thus, provided the basis for substantially increased revenues.

\footnotetext{
48 The NBA created the D-League in 2001. Beginning in the 2017-18 season, it was renamed the G-League as part of a multi-year sponsorship by Gatorade. Players who play in Europe can start as high as $\$ 100,000$ and often also receive living expenses. See, e.g., Darren Heitner, NBA D-League vs. European Basketball: Why Don't More Players go to Europe, Sports Agent Blog (July 30, 2012), http://sportsagentblog.com/2012/07/30/nba-d-league-vs-european-basketballwhy-dont-more-players-go-to-europe/; see also Dennis Hui, Unionizing the NBA G League, 25 Sports LaWYers J. 119 (2018). Also, starting in the summer of 2019, the G League will offer elite prospects that are 18 years old and, thus, too young to play in the NBA, $\$ 125,000$ per year. The G League will target the "one-and-done" college players. See Johnathan Givony, G League to Offer $\$ 125 \mathrm{~K}$ to Elite Prospects as Alternative to College One-and-Done Route, ESPN (Oct. 24, 2018), http://www.espn.com/nba/story//id/25015812/g-league-offer-professional-path-elite-prospectsnot-wanting-go-one-done-route-ncaa.

49 Travis Waldron, A Trip to the Men's Room Turned Jeff Kessler into the NCAA's Worst Nightmare, Huffington Post (Aug. 7, 2017), https://www.huffingtonpost.com/entry/jeffrey-kessler-ncaa-lawsuit us 59723f33e4b00e4363df3f59.

50 Steven Kutz, NFL Took in $\$ 13$ Billion in Revenue Last Season-See How It Stacks Up Against Other Pro Sports Leagues, Marketwatch (July 2, 2016), https://www.marketwatch.com/story/thenfl-made-13-billion-last-season-see-how-it-stacks-up-against-other-leagues-2016-07-01.

${ }^{51} I d$.
} 
To get a sense of how much more revenue college sports generates today than when Board of Regents was decided, we can look at the television contracts executed by the NCAA that were the subject of that litigation. The NCAA had four-year television agreements with ABC and CBS that ran through the 1985 season, with each network paying a minimum of $\$ 131.75$ million for broadcasting at least 35 games each year. In addition, there was a two-year, \$18 million deal with Turner Broadcasting. Thus, the average annual television revenues for all college football games televised were approximately $\$ 75$ million. ${ }^{52}$ According to an article by Paula Lavigne of ESPN.com, in 2015 the Power Five conferences alone received $\$ 1.4$ billion from selling TV rights. $^{53}$

USA Today's annual college revenue from sports breakdown in 2016-17 showed that the University of Texas topped the list, producing over \$215 million in revenue, followed by Texas A\&M at nearly $\$ 212$ million. These Texas schools were followed by Ohio State, Michigan, Alabama, Georgia, and Oklahoma, all of which bring in over $\$ 150$ million in annual revenue. There were 30 public universities on the list - more than double the amount from 2013 - whose athletic department revenues exceed $\$ 100$ million. ${ }^{54}$ More than 50 public universities reported revenues from their athletic departments in excess of $\$ 50$ million. ${ }^{55}$ As further evidence of the escalating proceeds generated by college sports, the median generated revenue of the FBS football programs increased by more than $160 \%$ between 2004 and 2014, to $\$ 21.7$ million, and for men's basketball it increased by almost $45 \%$ over that time, to $\$ 5.8$ million. $^{56}$

\footnotetext{
52 Linda Greenhouse, N.C.A.A. Plea in High Court; Controlling TV Football at Stake, N.Y. Times (Oct. 18, 1983), http://www.nytimes.com/1983/10/18/sports/ncaa-plea-in-high-court-controling-tvfootball-at-stake.html http://www.ncaa.org/student-athletes (last visited Feb. 2, 2018).

53 Paula Lavigne, Rich Get Richer in College Sports as Poorer Schools Struggle to Keep Up, ESPN (Sept. 6, 2016), http://www.espn.com/espn/otl/story/_id/17447429/power-5-conferenceschools-made-6-billion-last-year-gap-haves-nots-grows (last visited Feb. 2, 2018).
}

54 NCAA Finances 2016-17: Top School Revenue, USA ToDAY, http://sports.usatoday.com/ncaa/fi-

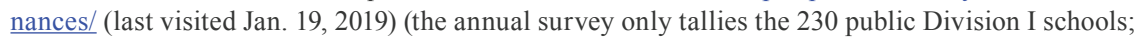
private colleges and universities are excluded). Amounts used were Total Revenues-allocated revenues. Allocated revenues are not generated by the athletic department, but include student fees, expenses paid for by the schools, and state and local government money provided to athletics.

55 Id. While the revenues that sports generate for colleges and universities are significant, they do not rival the amounts from professional sports teams. For example, annual revenues of NFL football teams range from the Dallas Cowboys' \$560 million to the Oakland Raiders' \$244 million. Kurt Badenhausen et al., Cowboys Are the First U.S. Team to Top \$3B Valuation, Forbes (Aug. 20, 2014), http://www.forbes.com/nfl-valuations/ (last visited Jan. 27, 2018). Annual revenues for NBA teams range from the $\$ 293$ million for the Los Angeles Lakers to \$110 million for the Milwaukee Bucks. Kurt Badenhausen et al., Lakers Top 2015 List of NBA's Most Valuable Teams; Average Franchise Is Now Worth Record \$1.1 Billion, ForBes (Jan. 21, 2015), http://www.forbes.com/sites/ kurtbadenhausen/2015/01/21/average-nba-team-worth-record-1-1-billion-2/.

56 The NCAA defines operating surplus as generated revenues, including donations, less operating costs, where such costs excludes most capital expenses. See Daniel L. Fulks, NCAA, Revenues \& Expenses: 2004-2014 NCAA Division I Intercollegiate Athletics Programs Report 11, 
The NCAA has also reaped huge benefits from increasing college sports revenues. The vast majority of the NCAA's revenues come from the operation of the NCAA men's basketball tournament. The first one was held in March of 1939 and lost money. ${ }^{57}$ In 1985, the NCAA received \$31 million from the television rights for the NCAA Tournament. ${ }^{58}$ However, as previously mentioned, in 2010 it signed a 14-year, \$11 billion deal for the broadcasting rights to the NCAA Tournament. ${ }^{59}$ In fiscal year 2014, the NCAA's total revenues exceeded $\$ 1$ billion, with the majority of those revenues, about $\$ 700$ million, coming from television and marketing agreements with CBS and Turner Broadcasting for the NCAA Tournament. ${ }^{60}$ Most of the other revenue generated by the NCAA is also tied to the NCAA Tournament, including ticket sales to live games. Of course, the NCAA distributes a significant portion of its revenues to its member schools and conferences, including, for example, \$547.1 million given to Division I schools and conferences from 2014 revenues. ${ }^{61}$ In 2016, the NCAA signed an eight-year extension agreement with CBS and Turner for the television rights for the NCAA Tournament, taking it through 2032. As part of the extension, the networks agreed to increase the amount the NCAA receives by an additional $\$ 8.8$ billion. ${ }^{62}$ The NCAA's net assets also doubled between 2006 and 2012 to over $\$ 566$ million. $^{63}$ The NCAA also had a surplus in 2014 of nearly $\$ 80.5$ million. ${ }^{64}$ This increased NCAA assets to almost $\$ 708$ million. ${ }^{65}$ But the NCAA incurred significantly more expenditures in 2016, \$1.4 billion, which dropped its total assets down to a little under $\$ 300$ million. ${ }^{66}$

\footnotetext{
27 (2015), http://www.ncaa.org/sites/default/files/2015\%20Division\%20I\%20RE\%20report.pdf.

57 See Joseph N. Crowley, In the Arena: The NCAA's First Century 31 (NCAA 1st ed. 2005) ("It was held in March that year, minus the madness ... [i]t produced a loss of \$2,531.”).

58 James V. Koch, The Economic Realities of Amateur Sports Organization, 61 InD. L.J. 9, 14 (1985).
}

59 Thomas O'Toole, NCAA Reaches 14-Year Deal with CBS/Turner for Men's Basketball Tournament, Which Expands to 68 Teams for Now, USA TodAY (Apr. 22, 2010), http://content.usatoday. com/communities/campusrivalry/post/2010/04/ncaa-reaches-14-year-deal-with-cbsturner/1\#. WmTUmmdEAoJ.

60 Steve Berkowitz, NCAA Nearly Topped \$1 Billion in Revenue in 2014, USA TodAY (March 11, 2015), http://www.usatoday.com/story/sports/college/2015/03/11/ncaa-financial-statement-2014-1-billion-revenue/70161386/.

61 Id.

62 Sherman, supra note 31.

63 See Steve Berkowitz, NCAA Had Record \$71 Million Surplus in Fiscal 2012, USA TodAy (May 2, 2013), http://www.usatoday.com/story/sports/college/2013/05/02/ncaa-financialstatement-surplus/2128431/.

${ }^{64}$ See Berkowitz, supra note 61.

65 Id.

${ }^{66}$ See Steve Berkowitz, NCAA Incurred \$1.4 Billion in Expenses in 2016, USA Today (Mar. 7, 2017), https://www.usatoday.com/story/sports/college/2017/03/07/ncaa-incurred-14-billion-in-expenses-in-2016/98856520/. 


\section{B. Are College Athletes in Revenue Sports Undercompensated?}

Before 2015, NCAA rules limited the amount of athletic scholarships to the cost of tuition and fees, room and board, and required course-related books. ${ }^{67}$ These "grant-in-aid" amounts never covered the full "cost of attending" college, because they did not include funds for miscellaneous expenses such as incidentals, laundering clothes, books not required for courses, entertainment, and transportation, including for trips to and from the athlete's permanent residence. These additional amounts are determined based on the cost of living at a given school's location and are, therefore, calculated by the financial aid officers who use their professional judgement under the authority of the U. S. Department of Education. ${ }^{68}$ Thus, the amounts for miscellaneous expenses vary from one institution to the next. However, commentators have generally estimated the average of these expenses at between $\$ 3,000$ and $\$ 6,000 .{ }^{69}$ Now, institutions are free to offer athletic scholarships up to the cost of attendance. The first year the NCAA member institutions could offer cost-of-attendance scholarships, the Power Five Conferences agreed to do so. ${ }^{70}$ A number of other non-Power Five Conferences have followed this example, including the MidAmerican Conference, the Horizon League, the Big South, and schools including the College of Charleston and Towson University. ${ }^{71}$

To determine whether athletes in revenue sports are underpaid, it is necessary to first establish how much they receive. Since the athletes' compensation is limited to the cost of attending their universities, the place to start is how much it costs to attend college. According to the 2018 college pricing report by the College Board, the average 2018-19 academic cost of tuition and fees, and room and board at four-year public institutions is $\$ 21,370$ for resident (in-state) students and $\$ 37,430$ for non-resident students. The average was $\$ 48,510$ for private nonprofit four-year institutions. ${ }^{72}$ To approximate the amount of a full cost-of-attendance scholarship, we need to add the cost of textbooks for courses and miscellaneous amounts. We should add an additional \$2,000 for books and miscellaneous amounts between $\$ 3,000$ and $\$ 7,000$. Thus, the range of cost of

\footnotetext{
67 O’Bannon, 7 F. Supp. 3d 955, 971 (2014).

68 Steve Berkowitz, NCAA Increases Value of Scholarships in Historic Vote, USA TodAY (Jan. 17, 2015), https://www.usatoday.com/story/sports/college/2015/01/17/ncaa-convention-cost-of-attendance-student-athletes-scholarships/21921073/.

69 Michael McCann, Stakes and Stakeholders in Alston v. NCAA, the Latest College Sports Antitrust Case, SPORTs Illustrated (Sept. 2, 2018), https://www.si.com/college-football/2018/09/04/ alston-v-ncaa-trial-news-updates-ncaa-cost-attendance.

70 Jake New, Autonomy Arrives at the NCAA, Inside Higher EduCATion (Jan. 19, 2015), https:// www.insidehighered.com/news/2015/01/19/power-five-leagues-expand-athletic-scholarships-cover-full-cost-attendence (last visited Feb. 3, 2018).

71 For a reference on the Mid-American Conference, the Horizon League, and the Big South Conferences see Adam Epstein and Paul M. Anderson, The Relationship Between a Collegiate Student-Athlete and the University: An Historical and Legal Perspective, 26 Marq. Sports L. Rev. 287, 293 (2016).

72 College Board, Trends In College Pricing 2018, 9 tbl.1 (2018), https://trends.collegeboard. org/sites/default/files/2018-trends-in-college-pricing.pdf.
} 
attending a Division I college or university would run between approximately $\$ 26,370$ and $\$ 57,510$. However, these amounts may overstate the cost of attending the college of one's choice because higher education institutions often discount tuition and fees. ${ }^{73}$ Separate from the cost reported by colleges and universities to attend their institutions, the results of a 2016 survey of NCAA Division I schools showed that the average athletic scholarships for men's basketball was $\$ 38,246$ and for FBS football it was $\$ 36,070$. $^{74}$

There are a number of different ways to try to determine the value of college athletes in revenue sports to their institutions. One way is to draw comparisons with the compensation of professional athletes. Unlike college athletes, both NFL and NBA players have unions to represent their interests and negotiate with the owners on their behalf. Under the current NFL collective bargaining agreement ("CBA") that runs through the 2020 season, the players receive a minimum of $47 \%$ of league-wide revenue. ${ }^{75}$ The NBA players receive a $50-50$ split of basketball-related revenue under the terms of their 10-year CBA signed in December $2011 .^{76}$ Yet, if you take the 2014 average revenue for an FBS football program of 21.7 million and divide it by 85 scholarship athletes you come up to over $\$ 255,000$ in revenue generated by each athlete. Since NFL players receive at least $47 \%$ of the revenue, if college football players received a similar percentage they would each receive approximately $\$ 127,000$ per year. As for men's basketball, the corresponding average revenue for the 13 scholarship basketball athletes is $\$ 446,000$. At the NBA collective bargaining percentage of $50 \%$, they would receive on average $\$ 223,000$ per year.

Ramogi Huma and Ellen J. Staurowsky ${ }^{77}$ conducted a collaborative study between the National College Players Association and Drexel University's Sports Management program of the amateur/athlete model. They concluded that the market value for big-time college football and men's basketball players is \$137,357 and \$289,031, respectively. ${ }^{78}$ Recently, Richard Borghesi, an associate professor of Finance at the University of South Florida, conducted a study of FBS football recruits in which he concluded that five-star players would be entitled to

\footnotetext{
73 According the College Board, the discounts for public four-year institutions for resident students is about $\$ 6,500$ and for private nonprofit four-year institutions it is $\$ 21,220$. Id at 18-19.

${ }^{74}$ Average Athletic Scholarship per Varsity Athlete, ScHOLARship Stats, http://www.scholarshipstats.com/average-per-athlete.html (last visited January 21, 2019).

75 Gary Myers, NFL Collective Bargaining Agreement Includes No Opt-Out, New Revenue Split, Salary Cap, Rookie Deals, Daily News (July 26, 2011), http://www.nydailynews.com/sports/ football/nfl-collective-bargaining-agreement-includes-no-opt-out-new-revenue-split-salary-caprookie-deals-article-1.162495.

76 See NBA, CBA 101: Highlights of the 2011 Collective Bargaining Agreement Between the National Basketball Association and the National Basketball Players Association (2012), http://www.nba.com/media/CBA101 9.12.pdf.

77 Ramogi Huma is the president, National College Players Association, and Ellen J. Staurowsky, EdD, is a professor of sport management at Drexel University.

78 Ramogi Huma and Ellen J. Staurowsky, The \$6 Billion Heist: RobBing College Athletes Under the Guise of Amateurism 12 (2012), available at http://assets.usw.org/ncpa/pdfs/6-BillionHeist-Study_Full.pdf.
} 
an additional $\$ 799,000$ per year, four-star players an additional $\$ 361,000$, threestar players an additional $\$ 29,000$, and two-star players an additional $\$ 21,000 .^{79}$

Examining the numbers suggests that there is a plausible argument that the players of revenue sports are generating far more revenues for their institutions than the compensation they receive from them. The average range for how much their financial compensation is from their Division I institutions is somewhere between approximately $\$ 26,370$ for athletes who are receiving grant-in-aid scholarships to attend their in-state public universities to about $\$ 57,510$ for those receiving cost-of-attendance scholarships at private institutions. Conversely, various attempts to determine the value of athletes playing revenue sports places that value at amounts beyond the scholarships they receive.

\section{Financial Consequences of Not Paying Athletes Have Benefited Their Coaches and Athletic Administrators}

Freed from the need to provide additional compensation to student-athletes in the revenue sports, the amounts colleges and universities spend on other parts of their athletic sports programs have exploded. And this arms race is continuing. ${ }^{80}$ Over the past 45 years, salaries that colleges and universities pay to their successful coaches in revenue sports have skyrocketed. Economist theorize that college coaches are overcompensated because athletes are not paid. ${ }^{81}$ The highest paid state official in 39 of the 50 states is an FBS football or men's basketball head coach. ${ }^{82}$ The average salaries for the 44 head football coaches in the NCAA Bowl Championship Series increased from $\$ 273,300$ in 1986 to $\$ 2,054,700$ by 2013, ${ }^{83}$

\footnotetext{
79 Richard Borghesi, Pay For Play: The Financial Value of NCAA Football Players, 49 ApPLIED ECONOMICs 46, 57 (2017).

80 The "arms race" metaphor comes from Knight Commission, A Call to Action Reconnecting College Sports and Higher Education (2001), http://www.knightcommission.org/images/ pdfs/2001_knight_report.pdf. See also Alfred Dennis Matthewson, Exploring the Commercialized Arms Race Metaphor, in Reversing Field: Examining Commercialization, Labor, Gender, and Race In 21st Century Sports Law 34, 35 (Eds. Andr'e Douglas Pond Cummings \& Anne Marie Lofaso, 2010).

${ }^{81}$ See Patrick McLaughlin, College Football Players, Not Coaches Deserve to Be Paid, NEwSDAY (Jan. 7, 2016), https://www.newsday.com/opinion/oped/college-football-players-not-coaches-deserve-to-be-paid-1.11301251.

82 Cork Gaines, The Highest-Paid Public Employee in 39 U.S. States is Either A Football or Men's Basketball Coach, Business Insider (Sept. 22 2016), http://www.businessinsider.com/usstates-highest-paid-public-employee-college-coach-2016-9/\#10-pennsylvania--james-franklin-44million-1. The states where this was not the case were Alaska, Delaware, Hawaii, Maine, Montana, Nevada, New Hampshire, New York, North Dakota, South Dakota, and Vermont. For a list of the highest paid person in each state, see Evan Comen et al., The Highest Paid Public Employee in Every State, 24/7 Wall Street (Sept. 20, 2016), http://247wallst.com/special-report/2016/09/20/ the-highest-paid-public-employee-in-every-state/2/.

83 See Marc Edelman, The Future of Amateurism After Antitrust Scrutiny: Why a Win for the Plaintiffs in the NCAA Student-Athlete Name \& Likeness Licensing Litigation Will Not Lead to the Demise of College Sports, 92 OR. L. REv. 1019, 1032 (2014).
} 
while over the same time the cost of living only doubled. ${ }^{84}$ The compensation for successful coaches has likewise climbed sharply. Compared Wooden's $\$ 40,000$ salary to that of recently fired UCLA head basketball coach Steve Alford, who earned $\$ 2.6$ million. ${ }^{85}$ The annual salary paid by the University of Oklahoma to its head football coach has increased from the $\$ 60,000$ paid to Barry Switzer to the over $\$ 5$ million to be paid to Lincoln Riley. ${ }^{86}$ In fact, the compensation of the most successful head coaches in revenue sports has reached amounts nearly as high as those for Fortune 500 CEOs. ${ }^{87}$ According to USA Today, the highest paid college basketball coaches in 2018 were Duke's Mike Krzyzewski (nearly \$9 million), Kentucky's John Calipari (nearly \$8 million), Ohio State's Chris Holman (\$7.15 million), Kansas’s Bill Self (\$4.95 million), and Michigan State’s Tom Izzo (\$4.36 million). ${ }^{88}$ According to USA Today, Nick Saban, the head football coach at the University of Alabama, is the highest paid head football coach, receiving $\$ 8.3$ million per year, ${ }^{89}$ while Ohio State's Urban Meyer (now retired) earned \$7.6 million, Michigan's Jim Harbaugh \$7.5 million, and Texas A\&M's Jimbo Fisher $\$ 7.5$ million, while Auburn's Gus Malzahn, Georgia’s Kirby Smart, Clemson's Dabo Swinney, and Florida's Dan Mullen all earned more than \$6 million..$^{90}$

The increases in expenditures for college sports do not stop with head coaches in revenue-generating sports. Will Hobson and Steven Rich noted that between 2004 and 2014 non-coaching payrolls of the athletic departments of the 48 schools in the five wealthiest conferences increased from $\$ 454$ million to $\$ 767$ million, a $70 \%$ increase in a decade..$^{11}$ Athletic departments also have more funds

\footnotetext{
84 U.S. Dep't. Of Labor, Bureau of Labor Statistics Consumer Price Index Calculator, https:// www.bls.gov/data/inflation calculator.htm.

85 Sable, supra note 40.

86 Kalen Jones, Oklahoma, Lincoln Riley Agree to Contract Extension, Sports Illustrated (Jan.

1, 2019), https://www.si.com/college-football/2019/01/01/oklahoma-lincoln-riley-contract-extension-agree.

87 In 2012, the average CEO of the largest U.S. companies earned \$12.3 million. Jennifer Liberto, CEOs Earn 354 Times More Than Average Worker, CNN Money (Apr.15, 2013), http://money.cnn. com/2013/04/15/news/economy/ceo-pay-worker/.
}

${ }^{8}$ NCAA Salaries: Top NCAAB Coach Pay, USA Today, http://sports.usatoday.com/ncaa/salaries/ mens-basketball/coach/ (last visited Jan. 27, 2019).

89 NCAA Salaries, USA ToDAY, http://sports.usatoday.com/ncaa/salaries/ (last visited Jan.18, 2019). Another article also reported that Nick Saban was the highest paid college football coach, receiving over \$11 million a year from the University of Alabama. Indeed, Saban's salary means that he makes more than all NFL coaches even though the Alabama football program produces less than one-third the income of any NFL team. Will Hobson and Emily Guskin, Poll: Majority of Black Americans Favor Paying College Athletes; 6 in 10 Whites Disagree, Wash. Post (Sept. 14, 2017), https://www.washingtonpost.com/sports/colleges/poll-majority-of-black-americansfavor-paying-college-athletes-6-in-10-whites-disagree/2017/09/14/27fa5fc2-98df-11e7-87fc$\mathrm{c} 3 \mathrm{f} 7 \mathrm{ee} 4035 \mathrm{c} 9$ story.html?noredirect $=$ on\&utm term $=.1251 \mathrm{cc} 1048 \mathrm{e} 0$

90 NCAA Salaries, USA ToDAY, http://sports.usatoday.com/ncaa/salaries/ (last visited Jan.18, 2019).

91 Will Hobson and Steven Rich, As College Sports Revenues Spike, Coaches Aren't Only Ones Cashing In, WASH. Post (Dec. 29, 2015), https://www.washingtonpost.com/sports/as-collegesports-revenues-spike-coaches-arent-only-ones-cashing-in/2015/12/29/bbdb924e-ae15-11e5-9ab0$\underline{884 d 1 \mathrm{cc} 4 \mathrm{~b} 33 \mathrm{e} \text { story.html?utm term }=.95 \mathrm{dc} 946 \mathrm{f} 7650}$ (last visited Feb. 3, 2018). 
to spend on sports facilities. In 2014, one in five Division I athletic directors said their departments planned on spending more than $\$ 50$ million on facilities in the next five years. ${ }^{92}$

\section{Limits of and Obstacles to Abandoning the Amateur/Education Model}

When speaking about football players, legendary Ohio State head coach Woody Hayes succinctly summarized the quid pro quo of the amateur/education model.

The coach will squeeze every bit of football from each player that he can, but in return the coach must give that man every legitimate measure of help he needs to get 'the rest' of his education. ... [W] e feel that the man who plays college football and does not graduate has been cheated. ${ }^{93}$

Under this model, the maximum obligation of the institution to the athlete is to provide scholarships to cover all costs related to pursuing a four-year academic degree and the academic support necessary to give athletes a realistic opportunity to obtain that degree.

For black athletes in the revenue sports, during the time Hayes was patrolling the sidelines at Ohio State, his view of college sports was more the exception than the rule. For example, a 1982 article in the Sporting News revealed that only 50\% of seniors regularly playing basketball in seven major conferences graduated with a degree, and in the Southwest Conference the figure was only $17 \%{ }^{94}$ A survey during the 1980s of 100 Division I basketball and football programs showed that at 35 of the schools the graduation rate for male basketball players was under $20 \%$ and the same was true at 14 of these institutions for football players. ${ }^{95}$ No doubt if the academic performance of black male athletes were separated out, the figures would be lower. In "Dunk and Flunk," Gladwell pointed out that only one fourth of the nation's black male athletes in major college sports graduated from college and $75 \%$ of them had degrees in physical education. ${ }^{96}$

Sometimes responding to public criticism, sometimes under the threat of litigation, and sometimes based on its own initiatives, the NCAA and its member institutions have made tremendous strides toward improving both academic achievement by students in revenue sports and increasing the value of their scholarships over the past 35 years. While there is still much to be done to make

\footnotetext{
92 Kevin Trahan, 84 Percent Of Colleges to Spend More On Sports Facilities, Per Survey, SB NATiOn (Aug. 27, 2014), http://www.sbnation.com/college-football/2014/8/27/6074901/college-sports-facilities-buildings-budgets.

93 Woody Hayes, You Win With People! 12 (2d ed. 1975).

94 Norton, supra note 22.

95 See Douglas Lederman, College Athletes Graduate at Higher Rate Than Other Students, But Men's Basketball Players Lag Far Behind, Survey Finds, Chron. OF Higher Educ., Mar. 27, 1991, at Al.

96 Gladwell, supra note 22.
} 
the promise of a genuine opportunity for a meaningful college degree an absolute reality, the NCAA and its Division I member institutions have traveled a long way down this road.

The first subsection of this part will discuss a number of changes instituted by the NCAA to increase academic requirements for entering high school students who are playing college sports. These increases had a special impact on those student-athletes in revenue sports. These increased requirements helped to ensure that more prospective high school athletes are academically prepared for the rigors of college study. The NCAA also instituted progression towards degree requirements to make sure that once student-athletes are enrolled they are making progress toward graduation.

The second subsection covers the adoption of the Academic Progress Rate. This measure provides an incentive to the member institutions to ensure that their athletes remain academically eligible and are progressing toward a college degree in each sport, including football and basketball. Failure of an institution to do so can lead to sanctions imposed by the NCAA.

With regard to financial support to pay for the cost of a college education, as previously noted, until the last few years the NCAA limited the amount of athletic scholarships to grant-in-aid expenses and for one year, renewable at the option of the institution. Due to antitrust litigation, the NCAA has repealed these limits. Conferences and member institutions are now able to offer multi-year scholarships that can cover the full cost of attendance. The third subsection surveys these recent increases in the value of the financial support that college athletes are receiving.

There is evidence that all of these changes are improving persistence and graduation rates of athletes, especially those of black males in revenue sports. This evidence is discussed in the fourth subsection of this part. Even if the NCAA allowed its member institutions (voluntarily or as a result of court injunctions) to pay athletes in revenue sports compensation beyond the cost of attending their institutions, there are several significant legal obstacles that colleges and universities desiring to do so will encounter. Addressing these obstacles may substantially increase the cost for member institutions that chose to abandon the amateur/education model. Thus, while certainly some universities will decide to provide compensation to their athletes in revenue sports beyond the cost of attendance, it is unlikely that many member institutions would have the desire and the ability to do so. These challenges are delineated in the final section of this part.

\section{A. NCAA and Member Institutions' Efforts to Improve Academic Performance by Adopting and Increasing Academic Eligibility Requirements for Athletes}

Since 1983, the NCAA has consistently increased academic requirements for athletes competing in Division I sports. To truly appreciate the scope of the problem of lack of academic achievement by black male athletes in revenue sports, it is necessary to take into account the massive societal changes that led to the opening of mainstream colleges and universities to blacks that started 
about 60 years ago. As William Bowen and Derek Bok noted in their hugely influential book, THE SHAPE OF THE RIVER, "it is probably safe to say ... that prior to 1960 , no selective college or university was making determined efforts to seek out and admit substantial numbers of African Americans," ${ }^{97}$ and, hence, recruit black male athletes. A few black players could be found playing for major college programs in the North and West before this time, but almost none in the South. This would start to change with the Civil Rights Movement of the 1960s. However, due to its historical animosity to black equality, it would take longer for universities in the South to enroll black athletes. President John F. Kennedy had to call out the National Guard in order to ensure the registration of James Meredith at Ole Miss in the fall of 1962. And Alabama's governor, George Wallace, delivered an infamous inauguration speech at the portico of the Alabama State Capitol in January 1963 in which he proclaimed, "In the name of the greatest people that have ever trod this earth, I draw a line in the dust and toss the gauntlet before the feet of tyranny, and I say, segregation now, segregation tomorrow and segregation forever." ${ }^{\text {98 }}$ Indeed, legendary Alabama head football coach Bear Bryant wanted to recruit black players for years before Alabama did so, but couldn't due to Wallace's objection. ${ }^{99}$

It was not until Billy Jones of Maryland played in a basketball game during the 1965-66 season that the ACC had its first African-American basketball player. ${ }^{100}$ Elvin Hayes and Don Chaney were the first black basketball players to play for Guy Lewis at the University of Houston in 1966. ${ }^{101}$ And the first black to play for an athletic team in the SEC was Kentucky's Nat Northington when he played in a game at Indiana University in Bloomington on September 23, 1967. By the early 1970s, however, substantial recruiting efforts for black players by major colleges and universities were well underway. This led to a huge influx of black male athletes on Division I campuses during the 1970s and early 1980s. In about a generation, black athletes had gone from novelties on Division I college campuses to dominant sports figures. ${ }^{102}$

\footnotetext{
97 William Bowen and Derek Bok, The Shape of THe River 4 (1998).

98 All Things Considered, 'Segregation Forever': A Fiery Pledge Forgiven, But Not Forgotten, NPR (Jan. 10, 2013), https://www.npr.org/2013/01/14/169080969/segregation-forever-a-fiery-pledge-forgiven-but-not-forgotten.

99 Allen Barra, The Integration of College Football Didn't Happen in One Game, THe AtLantic (May 15, 2013), https://www.theatlantic.com/entertainment/archive/2013/11/the-integration-of-college-football-didnt-happen-in-one-game/281557/ (last visited Feb. 3, 2018).

100 Richard Lapchick, Breaking the College Color Barrier: Studies in Courage, ESPN (Feb. 20, 2008), http://www.espn.com/espn/blackhistory2008/columns/story?columnist=lapchick_richard\&id=3254974 https://www.theatlantic.com/entertainment/archive/2013/11/the-integration-ofcollege-football-didnt-happen-in-one-game/281557/ (last visited Feb. 3, 2018).

101 Guy V. Lewis II, Hall of Fame College Basketball Coach, Dies at 93, WASHington Post (Nov. 28, 2015), https://www.washingtonpost.com/sports/guy-v-lewis-hall-of-fame-college-basketballcoach-dies-at-93/2015/11/28/7767abfa-9526-11e5-b5e4-279b4501e8a6_story.html?utm term=. 2c2422a9024c.
}

102 Ronald A. Smith, Pay For Play: A History Of Big-Time College Athletic Reform, 151-3 (2010). 
Prior to 1964, the NCAA let each institution determine its own rules about their athlete's academic eligibility to play. However, that year the NCAA adopted a rule that required all prospective athletes have a minimum 1.6 predicted GPA at the institution where they sought to matriculate. This was determined by the student's high school GPA, class ranking, and combined SAT or ACT score, but varied for each institution.

In a hotly contested 1968 narrow vote, 163-160, the NCAA lifted its ban on freshmen eligibility in all sports other than football and basketball. ${ }^{103}$ Supporters of the measure argued that member institutions could save money by operating just one varsity squad per sport. Four years later, the restriction on basketball and football players was lifted. ${ }^{104}$

From the beginning, academically rigorous institutions complained about the 1.6 predicted GPA requirement. They argued that this requirement disadvantaged them because it did not take into account the academic strength of a given institution's academic programs. These institutions pointed out that a 1.6 GPA at their institution did not mean that an athlete was a marginal academic student. The rule also had a negative disparate effect on the ability of the academically more rigorous institutions to recruit black athletes at the time that many mainstream colleges and universities were finally starting to enroll meaningful numbers of other black students. ${ }^{105}$ These complaints led the NCAA to repeal the predicted 1.6 GPA requirement in 1973. As a result, the need for a prospective athlete to have a minimum 2.0 high school GPA was the only academic qualification imposed by the NCAA, as the number of black athletes on college campuses started to explode in the $1970 \mathrm{~s} .{ }^{106}$

After several academic scandals, in 1983, the NCAA adopted the controversial Proposition 48, which took effect in 1986. Prop 48 required that a prospective athlete who wanted to compete as a freshmen obtain a minimum 2.0 GPA in 11 core academic high school courses and an SAT score of at least 700 or an ACT score of at least 15. Athletes who met either (but not both) requirements were deemed partial qualifiers, could still enroll in the institution, and receive an athletic scholarship. However, a partial qualifier was not eligible to practice or play as a freshman. If the institution concluded that the athlete made satisfactory academic progress, then the athlete could play the following year.

Due to the racial differences in standardized test scores, Prop 48's negative disparate impact on prospective black male athletes was obvious. ${ }^{107}$ Richard Lapchick observed that if Prop 48 was in effect in 1981, it would have made

\footnotetext{
103 Walter Byers, Unsportsmanlike Conduct: Exploiting College Athletes 162 (1995).

104 Id.

105 Id. at 129.

106 Francis X. Dealy Jr., Win At Any Cost: The Sell Out of College Athletics 113 (1990). See also Jeffrey Waller, A Necessary Evil. Proposition 16 and Its Impact on Academics and Athletics in the NCAA, 1 DePaul J. Sports L. Contemp. Probs. 189, 192 (2003).

107 For example, in 1986, the mean SAT score for whites was 1038 and for blacks it was 839. NAT'L Ctr. For Educ. Stats., Fast Facts, https://nces.ed.gov/fastfacts/display.asp?id=171 (last visited Jan. 21, 2019).
} 
$69 \%$ of the black male scholarship athletes ineligible to participate in their sport during their first year. ${ }^{108}$ For the first two years after Prop 48 was adopted, but before it went into effect (1984-86), blacks would have constituted $92 \%$ of the academically ineligible basketball and $84 \%$ of the ineligible football players. ${ }^{109}$ In 1989, the NCAA increased the impact of Prop 48 by adopting Proposition 42. Where Prop 48 allowed member institutions to provide athletic scholarships to partial qualifiers, Proposition 42 eliminated that ability. The NCAA, however, did allow partial qualifiers to receive need-based scholarships that any other student at the institution was eligible to receive. Prospective athletes that did not meet either qualification, however, were banned from receiving even need-based scholarships. These collective measures led to a sharp drop in the participation rates of black athletes in Division I, from 24\% to 17\%. However, by 1993 the percentage of blacks in Division I sports had rebounded to $28 \% .{ }^{110}$

The NCAA increased academic requirements for freshmen again when it adopted Proposition 16 in 1992, which took effect in 1996. ${ }^{111}$ Prop 16 increased the number of core high school academic courses that each athlete had to take from 11 to 13 . This was increased again to 14 in 2003, and to 16 in 2008. Proposition 16 also introduced a sliding scale for the minimum GPA and SAT/ ACT scores. So, the higher the athlete's high school grades the lower his or her required corresponding SAT or ACT score could be and vice-a-versa.

Under the current sliding scale, if you have a:

- $3.55 \mathrm{GPA}$, then you need 400 on the SAT or 37 on the ACT

- $3.25 \mathrm{GPA}$, then you need 520 on the SAT or 46 on the ACT

- 3.00 GPA, then you need 620 on the SAT or 52 on the ACT

- $2.75 \mathrm{GPA}$, then you need 720 on the SAT or 59 on the ACT

- $2.50 \mathrm{GPA}$, then you need 820 on the SAT or 68 on the ACT

- $2.30 \mathrm{GPA}$, then you need 900 on the SAT or 75 on the ACT $\mathrm{AT}^{112}$

Under current NCAA regulations, an athlete can also be admitted to a university as an academic redshirt. These are high school students who don't meet the regular academic requirements, but have at least a 2.0 high school GPA and a corresponding SAT score.

- Under the current sliding scale, if you have a:

- $2.299 \mathrm{GPA}$, then you need 910 on the SAT or 76 on the ACT

- $2.20 \mathrm{GPA}$, then you need 940 on the SAT or 79 on the ACT

\footnotetext{
108 See Harry Edwards, Crisis of Black Athletes on the Eve of the 21st Century Society, 9, 10 (2000).

109 Id. at 10.

110 Art Padilla, Educating the Athlete, 22 J.C. \& U.L. 37 (1995).

111 The adoption of Proposition 16 was accompanied by litigation attacking it as racially discriminatory. See Cureton v. NCAA 252 F. 3d 267 (2001) and Pryor v. NCAA 288 F.3d 548 (2002).

112 For the sliding scale, see NCAA, Reference Center: Quick Reference Guide, http://fs.ncaa. org/Docs/eligibility_center/Quick_Reference_Sheet.pdf.
} 
- 2.10 GPA, then you need 980 on the SAT or 83 on the ACT

- 2.00 GPA, then you need 1020 on the SAT or 86 on the ACT ${ }^{113}$

As an academic redshirt, the athlete can receive a scholarship and practice, but not play in competition. ${ }^{114}$ The academic requirements were raised again for students enrolling in August 2016. While the number of core high school courses remained at 16, athletes must complete 10 of those courses before their seventh semester and 7 of the 10 must be in English, math, or natural/physical science.

Beyond the requirements for freshmen eligibility, in 2003 the NCAA has also adopted measures to ensure that athletes are progressing toward a college degree once they are enrolled. Prior to the start of their second year, athletes must have completed at least 24 semester hours (or 36 quarter hours) and obtain a GPA that is at least $90 \%$ of the minimum GPA required to graduate (1.8 if 2.0 is required). Starting their third year, athletes must designate a program of study that will lead to a bachelor's degree, complete $40 \%$ of academic requirements for that field of study, and obtain $95 \%$ of the minimum GPA required to graduate. Prior to the fourth year, the degree completion percentage increases to $60 \%$ and $100 \%$ of the GPA required to graduate, and prior to the fifth year, it increases to $80 \%$ toward the degree and $100 \%$ of the GPA. ${ }^{115}$

\section{B. Academic Progress Rate: Obligations of Member Institutions to Improve Academic Performance of its Athletes}

In May 2004, the NCAA adopted legislation that instituted a metric known as Academic Progress Rate (APR). NCAA president Myles Brand called the adoption of the APR the "most far-reaching effort of its kind in NCAA history."116 It was the first time the NCAA adopted a requirement that sanctioned the institutions for the lack of academic performance of their athletes. The APR provides an incentive to member institutions to strengthen their academic advising, counseling, and tutoring services provided to athletes.

APR is calculated for each team at an institution as well as for all the athletes of a given college or university. Under the APR, each student-athlete receiving athletically related financial aid earns one retention point for staying in school and one eligibility point for being academically eligible. A team's APR is calculated by taking the points earned by athletes and dividing them by the total points possible, then multiplying that figure by 1000 .

The NCAA initially set the minimum APR at 900. But in 2011, it increased it by requiring teams to meet a minimum four-year APR average of 930 (which

\footnotetext{
$113 \quad I d$.

114 Id.

115 NCAA, Division I Progress-Toward-Degree Requirements, http://www.ncaa.org/about/division-i-progress-toward-degree-requirements.

116 Smith, supra note 102, at 183.
} 
corresponds to a $50 \%$ graduation rate) that was to take effect in $2015-16 .{ }^{117}$ For an athletic team at a given school that fails to meet the minimum, it can suffer sanctions. In 2011, the NCAA instituted a three-level penalty structure. The first level provides for a reduction in possible practice time by four hours and one day per week. The second level involves a reduction in the number of competitions that a team can participate in during the regular or postseason. In carrying out APR sanctions in 2012, the NCAA ended up banning the University of Connecticut's men's basketball team and nine other schools from playing in the NCAA's men's basketball tournament, even though the Huskies had won the tournament two years earlier and finished that year with a 20-10 record. ${ }^{118}$ Eighteen teams were banned the following year, although 11 of them were historically black colleges and universities (HBCUs). ${ }^{119}$ The third level of punishment involves coaching suspensions, financial aid reductions, and restricted NCAA membership. ${ }^{120}$

\section{Multi-Year and Increases in Amount of Athletic Scholarships}

In 1956, the NCAA changed its constitution and bylaws to allow its member institutions to award scholarships based on athletic abilities. These new athletic scholarships could cover grant-in-aid amounts plus an additional \$15 per month for miscellaneous expenses, which remained in effect until 1976. ${ }^{121}$ The schools could pay an athlete's educational and living expenses for four years. However, during the four years the institution could not reduce the financial support to the athlete if the athlete decided to stop playing, was injured and couldn't play, or proved not as talented as the school had hoped. By the early 1960s, coaches and athletic directors were complaining about this system because it put the athletes in a very powerful position. In 1967, the NCAA adopted legislation that provided if the athlete only made token appearances at practice or did not show up, then the institution could consider such action as fraudulent misrepresentation and would constitute grounds for termination of financial aid. ${ }^{122}$ This definition of fraudulent misrepresentation still left the member institutions obligated to pay athletes who could not play due to injuries or recruiting mistakes. In 1973, the NCAA adopted a measure that limited athletic scholarships to one year,

\footnotetext{
117 Timothy Davis and Christopher T. Hairston, NCAA Deregulation and Reform: A Radical Shift of Governance Philosophy? 92 Oregon LaW Review 77, 130 (2014).

118 There were nine other schools that were also ruled ineligible for the NCAA Tournament along with UConn, Arkansas-Pine Bluff, California-Riverside, Cal State Bakersfield, Jacksonville State, Mississippi Valley State, North Carolina-Wilmington, Texas A\&M-Corpus Christi, Toledo, and Towson. See APR: Ten Teams Lose Postseason, ESPN (June 20, 2012), http://www.espn.com/ mens-college-basketball/story//id/8077431/connecticut-huskies-9-others-sit-postseason-apr.

119 N.C.A.A. Hands Out Postseason Bans for Academics, but UConn Is Back, N.Y. Times (June 11, 2013), http://www.nytimes.com/2013/06/12/sports/ncaabasketball/ncaa-hands-out-postseasonbans-for-academics-but-uconn-is-back.html.

120 See Academic Progress Rate Explained, NCAA, http://www.ncaa.org/aboutresources/research/academic-progress-rate-explained.

121 National Collegiate Athletic Association, 1956-57 Yearbook, at 4.

122 NCAA Proceedings of the 61st Annual Convention, Jan. 9-11, 1967, at 122.
} 
renewable at the option of the institution. ${ }^{123}$ Thus, an institution was under no obligation to provide a scholarship to its current athletes the next year, which became a common practice. For example, according to the National College Players Association, which claims 7,000 active members, 22\% of top Division I men's basketball players found their scholarships were not renewed between 2008 and 2009. ${ }^{124}$

Due to the risk of antitrust litigation, in recent years the NCAA has moved to increase the ability of member institutions to provide more financial support to athletes, including abandoning the renewable one-year scholarship limitation. ${ }^{125}$ Since 2012, the NCAA has allowed schools to provide multi-year scholarships. Member institutions are now in the position of deciding whether they will offer multi-year scholarships, how many they will offer, and to whom they will extend such offers. With multi-year scholarships, athletes will not lose their scholarships due to injury or inadequate athletic performance. Both the Big Ten and Pac 12 have agreed to offer multi-year scholarships to all of their athletes as long as the athletes follow team rules and remain academically eligible. ${ }^{126} \mathrm{~A}$ number of other schools, including Florida, South Carolina, Oklahoma State, Kentucky, Clemson, and Virginia, have also decided to offer multi-year scholarships. ${ }^{127}$

As with multi-year scholarships, antitrust litigation also led the NCAA to abandon its rules and regulations limiting the amount of the scholarship to grantin-aid amounts. In a class action case, White $v . N C A A,{ }^{128}$ football and basketball athletes challenged the NCAA limit on athletic scholarships to grant-in-aid amounts. They argued that colleges and universities should be allowed to offer cost-of-attendance scholarships. The court denied the NCAA's motion to dismiss the claim. As a result, the NCAA settled the case in 2008 and agreed to provide \$218 million to Division I schools for the benefit of student-athletes for the next five years, made $\$ 10$ million available for claims by qualified former student-athletes, permitted Division I schools to provide comprehensive health insurance to student-athletes, and permitted schools to provide insurance against sports-related injuries to student-athletes. ${ }^{129}$ But, the NCAA maintained the grant-in-aid limit on scholarships.

\footnotetext{
123 NCAA Const. ART. 15.3.3.1 (2011), reprinted in 2011-12 NCAA Division I Manual, Constitution, Operating Bylaws, Administrative Bylaws.

124 Branch, supra note 15.

125 Agnew v. NCAA, 683 F.3d 328 (7th Cir. 2012).

126 Ben Strauss, Colleges' Shift on Four-Year Scholarships Reflects Players' Growing Power, N.Y. Times (Oct. 14, 2014), http://www.nytimes.com/2014/10/29/sports/colleges-shift-on-four-yearscholarships-reflects-players-growing-power.html? $\mathrm{r}=0$ (last visited Feb. 3, 2018).

127 Jon Solomon, Schools Can Give Out 4-Year Athletic Scholarships, but Many Don't, CBS SPORTs (Sept. 16, 2014), https://www.cbssports.com/college-football/news/schools-can-give-out-4year-athletic-scholarships-but-many-dont/ (last visited Feb. 3, 2018).

128 White v. NCAA, No. CV 06-999-RGK (MANx), 2006 U.S. Dist. LEXIS 101366, at *1-2 (C.D. Cal. Sept. 20, 2006).

129 Thomas A. Baker III et al., White v. NCAA: A Chink in the Antitrust Armor, 21 J. Legal AsPECTS SPORT 75, 77 (2011).
} 
On August 8, 2014, Federal District Court Judge Claudia Wilken's opinion in O'Bannon $v$. $N C A A^{130}$ struck down the NCAA's grant-in-aid limit on the amount of that athletic scholarship for FBS football and men's basketball as an unreasonable restraint on trade. ${ }^{131}$ In her opinion, Judge Wilken did not preclude the NCAA from capping the amount of compensation that athletes received while in school. However, she did enjoin the NCAA from setting this cap amount below the cost-of-attendance expenses, as the term is defined in its current bylaws. ${ }^{132}$ Judge Wilken also prohibited the NCAA from enforcing any rules preventing a member school or conference from depositing up to $\$ 5,000$ a year of deferred compensation from funds derived by the use of student-athletes' names, images, or likenesses in an account for each of them as long they remained academically eligible to compete. However, the Court order did not prohibit the NCAA from enacting and enforcing rules that required each recruit in the same class to receive the same amount of deferred compensation. ${ }^{133}$ Also, the court order did not prohibit the NCAA from limiting the ability of its member institutions to place the deferred compensation funds in a separate account for the athletes that would not be distributed until after each athlete either left the institution or his or her eligibility expired. ${ }^{134}$ Prompted by this litigation, in January 2015, the NCAA repealed its rule that limited all athletic scholarships, including those in non-revenue sports, to grant-in-aid amounts.

On September 30, 2015, the 9th Circuit affirmed the part of Judge Wilken's decision that prevented the NCAA from setting a limit on the amount of the athletic scholarship below the cost-of-attendance amounts. All three judges agreed that the District Court was correct on this point. The 9th Circuit judges pointed out that student-athletes who receive the full cost of attendance for their services are still not receiving compensation beyond their college expenses. Allowing colleges and universities to pay the full cost of attendance of their athletes is completely consistent with amateurism and is a less restrictive way of advancing that pro-competitive justification than limiting the scholarships of athletes to grant-in-aid amounts. The deferred compensation was another matter. The judges split 2 to 1 on whether the District Court should have enjoined the NCAA from

\footnotetext{
130 O'Bannon, 7 F. Supp. 3d 955, 971 (2014) rev. O'Bannon v. NCAA, 802 F.3d 1049 (9th Cir., 2015) cert. den. 137 S. Ct. 277 (2016).

131 On August 8, 2014, Federal District Court Judge Claudia Wilken's opinion in O'Bannon v. NCAA, 7 F. Supp. 3d 955, 971 (2014) rev. O'Bannon v. NCAA, 802 F.3d 1049 (9th Cir., 2015) cert. den. 137 S. Ct. 277 (2016), struck down the NCAA's grant-in-aid limit on the amount of that athletic scholarship for FBS football and men's basketball as an unreasonable restraint on trade.

132 O’Bannon, at 7 F. Supp. at 1007-8.

133 Id. at 1008 ("Furthermore, consistent with Plaintiffs' representation that they are only seeking to enjoin restrictions on the sharing of group licensing revenue, the NCAA may enact and enforce rules ensuring that no school may offer a recruit a greater share of licensing revenue than it offers any other recruit in the same class on the same team."). Shortly after the decision, University of Texas athletic director Steve Patterson announced that it would start to pay each of its student-athletes $\$ 10,000$ per year, $\$ 5,000$ for COA payments and $\$ 5,000$ for use of its name and likeness. Zach Barnett, Texas Will Begin Paying Each of its Athletes \$10,000 Per Year, FootBall Scoop (Oct. 22, 2014), http://footballscoop.com/news/texas-will-begin-paying-athletes-10000-year/.

134 O’Bannon, at 7 F. Supp. at 1008.
} 
preventing member institutions and conferences from providing student-athletes with up to $\$ 5,000$ a year in deferred compensation. As the majority stated, "not paying student-athletes is precisely what makes them amateurs." 135 Thus, "the difference between offering student-athletes education-related compensation and offering them cash sums untethered to educational expenses is not minor; it is a quantum leap." ${ }^{36}$ Chief Judge Thomas opined in dissent that he would have upheld the lower court's injunction on this matter as well. ${ }^{137}$

At the NCAA's January 2015 Convention, the NCAA also restructured its rules to allow a groups of conferences and schools to govern themselves through autonomous regulations. The NCAA was responding to pressure brought by members of some of its major conferences and the University of Notre Dame. This measure provided the mechanism for the creation of the Power Five Conferences, who then approved a measure that increased their athletic scholarships to cover athletes' full cost of attendance. A number of other conferences followed suit. The result of these changes led to an almost 9\% gain in 2016 in the amount of financial aid provided by the 230 Division I schools' that USA Today tracks. This was the largest gain in financial aid for athletes since 2010. ${ }^{138}$

It is worth pointing out that the litigation in the O'Bannon case only involved athletes in revenue sports. However, the reaction by the conferences and institutions that agreed to increase their athletic scholarships to the cost-of-attendance amounts increased their scholarships for all athletes. So once again, the athletes in revenue sports are the impetus to improving the compensation provided to all college athletes.

\section{Evidence of Improved Graduation Rates}

The desire to win and the benefits that come from winning FBS football and men's basketball teams provides a strong incentive to colleges and universities to place the needs of their athletic programs above their academic interests. Thus, the revenue sports continue to be plagued by academic scandals such as the recent one at one of America's most venerated academic institutions, the University of North Carolina. ${ }^{139}$ Nevertheless, all of the changes previously noted appear to have increased the academic success of student-athletes in revenue-generating sports, especially black males.

\footnotetext{
135 O'Bannon, at 1076.

136 O’Bannon, at 1078.

137 O'Bannon v. NCAA, 802 F.3d 1049, 1079, 1083 (Thomas, Chief Judge, concurring in part and dissenting in part) (9th Cir. 2015).

138 Steve Berkowitz and Christopher Schnaars, Colleges Are Spending More on Their Athletes Because They Can, USA ToDAy (July 6, 2017), https://www.usatoday.com/story/sports/college/2017/07/06/colleges-spending-more-their-athletes-because-they-can/449433001/.
}

139 The scandal involved allegations that covered an 18-year period. Almost half of the 3,100 students were athletes who benefited from taking courses where professors gave high grades even though the students did not show up for class, turn in papers, or take tests. See Mike Rutherford, North Carolina Academic Scandal Will End Quietly, Just Like Everyone Wanted, SB Nation (June 5, 2015), http://www.sbnation.com/college-basketball/2015/6/5/8735807/north-carolina-basketball-academic-scandal-ncaa-2015. 
There are two different reported ways to assess academic success of student-athletes in college. The federal approach is essentially a two-snapshot approach to determining the percentage of college students at a given institution who graduated. One snapshot looks at the number of students who entered an academic institution and the second at how many of those who entered graduated from that institution six years later. As a result, this approach fails to account for students who transfer to a different institution and graduate. Indeed, any transfer student is treated as a dropout, even though as many as one-third of students transfer at least once while in college and still graduate. ${ }^{140}$

Since the NCAA and its member institutions track student-athletes for six years, they have the capabilities of taking into account transfers in their calculations of academic success. Thus, the NCAA developed the graduation success rate (GSR) approach in 2005 because it felt that there was a need for a more accurate measure of academic success than the methodology employed by the federal government. In contrast to the federal graduation rate, the GSR will add to the number of incoming freshmen in a given cohort students who first enter college in the middle of the first year, as well as transfer students who receive athletic aid. The GSR also deducts from the numbers of a given cohort allowable exclusions $^{141}$ and athletes who left their institution prior to graduation but still had athletic eligibility remaining and were academically eligible to compete had they returned to their institutions. While the GSR is more accurate than the federal approach, the GSR is not comparable to the graduation results generated by the federal approach.

Using federal graduation data, Shaun Harper, Collin Williams, and Horatio Blackman of the Center for the Study of Race \& Equity in Education at the University of Pennsylvania published a study of graduation results of the 76 member institutions of six major Division I conferences that existed at the time: the ACC, Big Ten, Big 12, Pac 12, SEC, and the old Big East. ${ }^{142}$ They found that across four cohorts that graduated between 2007 and 2010, the black male student-athletes graduated at a rate of $50.2 \%$ in six years. In contrast, they found that the percentage for black undergraduate males at these institutions who graduated in six years was 55.5\%. For comparisons, their study found that $66.9 \%$ of student-athletes overall, and $72.8 \%$ of undergraduate students overall graduated in six years. ${ }^{143}$ Harper did a follow-up study three years later and found that six-year graduation rates for all groups had improved. He found that " $53.6 \%$ of Black male student-athletes graduated within six years, compared to $68.5 \%$ of student-athletes overall, $58.4 \%$ of Black undergraduate men overall, and $75.4 \%$

\footnotetext{
140 Bernard Franklin, More Lightning and Less Thunder: The Challenge for NCAA Athletics 16, 17 in Reversing Field: Examining Commercialization, Labor, Gender, and Race In 21st Century Sports Law 34, 35 (Eds. Andr'e Douglas Pond Cummings and Anne Marie Lofaso, 2010).

141 Those who either die or become permanently disabled, those who leave the school to join the armed forces, foreign services, or attend a church mission.

142 Harper, supra note 18. Five schools included in the study (DePaul University, Marquette University, Providence College, Seton Hall University, and St. John's University) did not have football teams, so only basketball team members were included for them.
}

143 Id. at 2 . 
of undergraduate students overall." 144

Where the aforementioned study indicated that black male athletes had lower graduation rates than black male students on the same campuses, other evidence suggests that black male athletes are graduating at higher rates than other black males. Another study indicated that if you look at all black male athletes in Division I, they have graduated at higher rates than non-athlete black males every year during the study years of 1991-2017, but the gap has increased from $5 \%$ in 1991 (33\% to $28 \%$ ) to $15 \%\left(55 \%\right.$ to $40 \%$ ) in $2017 .{ }^{145}$ Michelle Brutlag Hosick agreed with the study's federal graduation rates in 2017 for black male student and non-student athletes in Division I, but went further. She found that black athletes (male and female) were outpacing all blacks in Division I, graduating at a rate of 59\% compared to $46 \% .^{146}$ The $59 \%$ graduation rate is a substantial increase from the $35 \%$ rate for the ones entering college in $1984 .{ }^{147}$ Another study pointed out that federal graduation rates for African-Americans in revenue sports are also higher than African-American males in the student body, men's basketball by $9 \%$ and FBS football by $13 \% .{ }^{148}$ This study also showed that between 1991 and 2017, the federal graduation rate for black men's basketball players had increased from $29 \%$ to $49 \%$ and for black male FBS football players from $35 \%$ to $60 \%$. $^{149}$

The GSR paints an even rosier picture regarding the increasing academic progress of black male student-athletes. In 2017, the GSR reached an all-time high of $87 \%$ for Division I athletes. ${ }^{150}$ The overall GSR for black male student-athletes

\footnotetext{
144 Id. at 1.

145 See Trends in Graduation Success Rates and Federal Graduation Rates at NCAA Division I Institutions, NCAA RESEARCH, at 52 (Nov. 2017), available at https://www.ncaa.org/sites/default/ files/2017D1RES Grad Rate Trends FINAL 20171108.pdf.) (last visited Jan. 19, 2019). In 1991 it was $33 \%$ compared to $28 \%$, but in 2017 it was $55 \%$ compared to $40 \%$. Id. There are still gaps with the corresponding white players. Thus, black male men's basketball federal graduation rates have closed from $24 \%$ to $13 \%$ and for black male FBS football from 21 to $14 \%$. Id.
}

146 Michelle Brutlag Hosick, DI African-American Student-Athletes Graduate at Record Rates, NCAA (Nov. 8, 2017), http://www.ncaa.org/about/resources/media-center/news/di-african-american-student-athletes-graduate-record-rates.

147 Id.

148 See Trends in Graduation Success Rates and Federal Graduation Rates at NCAA Division I Institutions, NCAA RESEARCH AT 41 (Nov. 2017), https://www.ncaa.org/sites/default/ files/2017D1RES Grad Rate Trends FINAL 20171108.pdf (last visited Jan. 19, 2019).

149 See Trends in Graduation Success Rates and Federal Graduation Rates at NCAA Division I Institutions, NCAA RESEARCH AT 44 (Nov. 2017), https://www.ncaa.org/sites/default/ files/2017D1RES Grad Rate Trends FINAL 20171108.pdf (last visited Jan. 19, 2019). There are still gaps with the corresponding white players. Thus, black male men's basketball federal graduation rates have closed from $24 \%$ to $13 \%$ and for black male FBS football from 21 to $14 \%$. Id.

150 A record $84 \%$ of Division I athletes who entered college in 2007 graduated six years later. Jake New, More Athletes Get to the Finish Line, Inside Higher Education (Oct. 29, 2014) (discussing the GSR vs. federal rate generally), https://www.insidehighered.com/news/2014/10/29/graduation-rates-athletes-hit-record-high (last visited Feb. 3, 2018). 
in Division I was $77 \%$, which is a $21 \%$ increase since $2002 .{ }^{151}$ In addition, $78 \%$ of black men's basketball players earned their degrees, which is up a staggering 32 points since $2002 .{ }^{152}$ For black football players who were enrolled in FBS schools, their GSR was a record $73 \%$, which is a 20 point increase since $2002 .{ }^{153}$ In a separate study, Lapchick reported that the average GSR for the black male athletes in the 80 Division I football schools that played in a bowl game in 2016 was $68 \%$, two percentage points higher than in $2015 .{ }^{154}$

\section{E. Legal Obstacles to Altering the Amateur/Education Model}

Even if the NCAA allowed its member institutions, voluntarily or as a result of court injunctions, to compensate athletes in revenue sports beyond cost-ofattendance scholarships, those that want to pay athletes will face a virtual legal minefield of potential problems. Colleges and universities will have to assure themselves that if they abandon the amateur/education model and pay their athletes in revenue sports it doesn't trigger a re-evaluation of whether the income they receive from these sports teams is unrelated business income for the higher education institution and, thus, subject to federal income taxes. The first section of this part will discuss this major issue. Member institutions will also have to determine the impact of paying some or all of their athletes in revenue sports on the athletic scholarships amounts beyond the cost-of-attendance scholarships. If doing so leads to a substantial amount of what athletes receive becoming subject to federal income taxes, then the colleges and universities will have to increase their compensation to the athletes to put them in the same position they are in today. The second section will address this issue. Paying athletes beyond the cost of attendance runs the risk that they will be viewed as employees under other statutory schemes that govern the employer/employee relationship. Consequently, as addressed in the third subsection, there are a number of collateral consequences that will result from athletes being considered employees under these other statutory schemes. All of these legal hurdles may prevent many, otherwise willing, institutions from abandoning the amateur/education model to provide additional compensation for their athletes. When these legal obstacles are taken together, despite current antitrust actions in the courts, it seems very unlikely that many colleges and universities will abandon the amateur/education model. ${ }^{155}$

\footnotetext{
151 Hosick, supra note 147.

152 Id.

153 Id.

154 Richard Lapchick et al., Inst. for Diversity and Ethics in Sports, KeEPING Score When IT Counts: Assessing the Academic Records of the 2016-2017 Bowl-Bound College Football TEAM (2016), http://nebula.wsimg.com/13533ce46b93ecad13c6a8304c43868f?AccessKeyId=DAC3A56D8FB782449D2A\&disposition=0\&alloworigin=1.

155 However, some commentators assume that these obstacles are not insurmountable and that paying athletes may not alter college sports very much. See, e.g., Jeffrey Standen, The Next LABor Market in Sports, 92 Or. L. Rev. 1093 (2014).
} 


\section{Could Income from Revenue Sports Become Taxable to the Member Institu- tions as Unrelated Business Income}

Under current federal income tax law, athletes in revenue sports who are receiving athletic scholarships are not considered employees. A few years ago, the Internal Revenue Service ("IRS") recently reiterated this point. The Northwestern University football players who receive scholarships for grant-inaid amounts filed a petition under the National Labor Relations Act ("NLRA") to have a representation election to elect the College Athletes Players Association to represent them for collective bargaining purposes. In March 2014, Regional Office 13 of the National Labor Relations Board ("NLRB") concluded that they did meet the definition of employees under the NLRA. ${ }^{156}$ In response to a letter from Senator Richard Burr, the IRS issued a letter ruling on April 9, 2014. Burr had asked the IRS about the potential tax implications of the "recent decision of a regional office of the National Labor Relations Board that all grantin-aid scholarship football players at Northwestern fall within the definition of employees under the National Labor Relations Act." ${ }^{157}$ In response, the IRS stated that the NLRB's decision does not control "whether the individual is an employee for federal tax purposes. Accordingly, the NLRB decision does not control the tax treatment of athletic Scholarships." 158

Based on data compiled from the Equity in Athletics Disclosure Act, between 2003 and 2014, FBS universities generated football-related revenues of $\$ 27.4$ billion. ${ }^{159}$ The corresponding expenses associated with these revenues, including athletic scholarships, was $\$ 16.8$ billion. This meant that those schools generated a net profit of $\$ 10.6$ billion dollars for those years. The broad tax exemption provided by IRC Section 501(c)(3), specifically includes educational institutions and amateur sport organizations in its list of organizations that serve

\footnotetext{
156 The NLRB, however, unanimously decided on August 17, 2015, not to assert jurisdiction over this attempt. 362 NLRB No. 167 (2015). The NLRB General Counsel, however, issued a memorandum on January 31, 2017, stating that he nevertheless found that FBS football players on scholarship were employees under the NLRA. See Memorandum GC 17-01, available at https:// www.nlrb.gov/reports-guidance/general-counsel-memos. But, some jurisdictions have passed laws to prevent student-athletes from unionizing; see also Ohio Rev. Code $\$ 3345.56$ (2015) and Mich. Comp. Laws 423.201 Sec. 1. (e) (iii) (2015) (An individual serving as a graduate student research assistant or in an equivalent position, a student participating in intercollegiate athletics on behalf of a public university in this state, or any individual whose position does not have sufficient indicia of an employer-employee relationship using the 20-factor test announced by the IRS of the United States Department of Treasury in revenue ruling 87-41, 1987-1 C.B. 296 is not a public employee entitled to representation or collective bargaining rights under this act.)

157 For a copy of the IRS letter to Senator Richard Burr, see https://www.irs.gov/pub/irs$\underline{w d / 14-0016 . p d f . ~}$

158 Id.

159 Richard Borghesi, Pay For Play: The Financial Value of NCAA Football Players, 49 APPLIED ECONOMICS 46, (2017).
} 
charitable purposes, public purposes, or both. ${ }^{160}$ As a result, non-profit colleges, universities, and the NCAA are exempt organizations. Currently, the IRS exempts income generated by colleges' and universities' revenue sports programs from taxation because the income is viewed as "substantially related" to a university's educational mission.

Up through 1950, exempt organizations were not subject to tax on any of their revenue as long as the funds were used to further their tax-exempt purposes. ${ }^{161}$ However, Congress enacted provisions that imposed a tax on the unrelated business income of tax-exempt organizations as part of the Revenue Act of $1950 .{ }^{162}$ Unrelated business income is revenue earned by a tax-exempt organization that is regularly carried on, but is not substantially related to the accomplishment of the organization's exempt purpose. ${ }^{163}$ In the regulations discussing unrelated business income, the IRS uses an example of selling tickets to a public performance by students to assert that this is not unrelated business income because the activity of teaching students how to perform in front of a live audience is part of performance art training. ${ }^{164}$ Arguably, this same rationale would apply to the sale of tickets to live college football and basketball games. With regard to the receipt by colleges and universities of television revenue for their athletic events, in 1977, the IRS concluded that income from broadcasting college sports events was taxable. ${ }^{165}$ This position, however, drew substantial public protest, leading the IRS to issue an unpublished Technical Advice Memoranda, which concluded that there was no material distinction between providing for a game to be seen in person by 100,00 people and providing for it to be seen by much larger audience on television. ${ }^{166}$

As for the NCAA and its revenue generated from the men's basketball tournament, the 10th Circuit in NCAA v. Commissioner of Internal Revenue concluded that the NCAA did not generate unrelated business income when it sold

\footnotetext{
160 Corporations, and any community chest, fund, or foundation, organized and operated exclusively for religious, charitable, scientific, testing for public safety, literary, or educational purposes, or to foster national or international amateur sports competition (but only if no part of its activities involve the provision of athletic facilities or equipment) . . Section 501(c)(3).

161 Richard L. Kaplan, Intercollegiate Athletics and the Unrelated Business Income Tax, 80 Colum. L. Rev. 1430, 1432-37 (1980).

162 According to Kaplan, "During the congressional hearings of 1950, witnesses expressed concern about many typical university enterprises - from bookstores to university presses to experimental farms. The committee reports responded to these concerns and referred to such operations as 'related' businesses, thereby exempting them from the new tax. But no mention of intercollegiate athletics can be found in the House or Senate hearings.” Id at 1436.

163 IRC $\S 513(\mathrm{a})$; Treas. Reg. § 1.513-1(d).

164 Treas. Reg. $\$ 1.513-1$ (d)(4)(i) ex. 1.

165 See IRS Tech. Adv. Mem. 78-51-002 (Jan. 1, 1978). The IRS notified several universities and the Cotton Bowl Athletic Association, the tax-exempt organization that sponsors the Cotton Bowl football game, that revenues from broadcasting the game constituted unrelated business income.

166 Id.; see also id., at 78-51-005 (Jan. 1, 1978); 78-51-006 (Jan. 1, 1978).
} 
advertisements in game programs during the tournament. ${ }^{167}$ The court stated that neither the tournament itself nor the sale of program advertising were unrelated business income because it was conducted for only a three-week period once a year; thus, the tournament was not a regularly carried on business. ${ }^{168}$

But in 1991, the IRS concluded that money received from corporate sponsorships of college football games was unrelated business income. ${ }^{169}$ Congress, however, responded to this decision six years later by enacting a specific exemption from unrelated business income for "qualified sponsorship." regulations promulgated pursuant to this Congressional act draw a distinction between income from sponsorships that are not taxable and income from advertising that is taxable. Basically, if the corporate sponsorship only allows a corporation to display its name, logo, or product lines, then the payment will qualify as "sponsorship" payment, not advertising.

All of this means that under current IRS interpretations, revenue generated from FBS football and men's basketball is not currently subject to federal income tax as unrelated business income for either the NCAA or its member institutions. If amateurism is rejected as a necessary components of college athletics, however, and Division I institutions begin to pay their athletes amounts beyond cost of attendance this could (and we stress "could") raise the question of whether the IRS should revisit the issue of whether the funds produced by revenue sports are unrelated business income for the colleges and universities. ${ }^{171}$

Closely related to this issue is the fact that contributions to athletic programs of Division I colleges and universities are tax exempt. But, if athletes in revenue sports are paid more in compensation it could negatively impact the tax-exempt status of athletic departments because member institutions would no longer be fostering amateur competition. ${ }^{172}$

\footnotetext{
167914 F.2d 1417, 1421-22 (10th Cir. 1990).

168 Id. at 1424-6.

169 IRS Tech. Adv. Mem. 91-47-007 (Nov. 22, 1991); For a discussion of this decision, see David A. Halmes, Corporate Sponsorships of Charity Events and the Unrelated Business Income Tax: Will Congress or the Courts Black the IRS Rush to Sack the College Football Bowl Games?, 67 Notre Dame L. Rev. 1079 (1992).

170 Roni A. Elias, Collegiate Athletics and the Unrelated Business Income Tax: Old Assumptions and New Directions for an Issue of Charitable Tax Exemptions, 5 ARIz. ST. SPORTs \& ENT. L.J. 50, 71-2 (2015).

171 For an article that discusses this issue, see Roni A. Elias, Collegiate Athletics and the Unrelated Business Income Tax: Old Assumptions and New Directions for an Issue of Charitable Tax Exemptions, 5 Ariz. ST. Sports \& Ent. L.J. 50 (2015).

172 See, e.g., Darren A. Heitner, Money and Sports: Economic Realities of Being an Athlete, 8 Depaul J. Sports L. \& Contemp. Probs. 161, 169 (2012). “[T]he term 'charitable contribution' means a contribution or gift to or for the use of a corporation, trust, or community chest, fund, or foundation organized and operated exclusively for religious, charitable, scientific, literary, or educational purposes, or to foster national or international amateur sports competition." 26 U.S.C.A. $\S 170(a)(1)$.
} 


\section{Taxable Implications of Athletic Scholarships}

Section 117 of the IRC provides that students can exclude from their income, for the purpose of determining federal income taxes, the amounts of a qualified scholarship. Such a recipient must be enrolled at an educational institution and the primary purpose of the scholarship must be to further the recipient's education. The IRS limits the amount of the exclusion to qualified expenses, which are defined as tuition, required fees, and/or books, supplies, and equipment required of all students in the course. ${ }^{173}$ Amounts used to cover room and board, however, are not excludable from gross income. ${ }^{174}$ Nor would amounts of a scholarship received for miscellaneous cost-of-attendance expenses be excluded.

Separate from the issue of the taxability of athletic scholarships, funds given to students by colleges and universities as compensation for past, present, or future employment services under the control of the university, or for studies or research for the primary benefit of the university, do not qualify as scholarships and are subject to federal income taxes. ${ }^{175}$ As a result, there is an argument that the IRS should have concluded that athletic scholarships for revenue sports were taxable some time ago, because given the revenue generated by FBS football and men's basketball, arguably, funds provided for services to the players on these teams are for the primary benefit of the university. But the IRS adopted Revenue Ruling 77263 more than 40 years ago. The ruling addressed the taxability of college athletic scholarships where the amount of the scholarship did not exceed "expenses for tuition and fees, room and board (or commuting and lunches), and books and supplies necessary for the student's studies." ${ }^{.176}$ In this ruling, the IRS concluded that athletic scholarships are excludable from the recipient's gross income.

Revenue Ruling 77-263 was issued seven years before the Supreme Court's opinion in NCAA v. Board of Regents, ${ }^{177}$ which is well before college sports became such a major commercial activity. And, the ruling was issued at a time when the NCAA's rule that limited athletic scholarships to one-year renewable grantin-aid amounts was in effect. The IRS has not addressed this ruling in the past 40 years. However, scholars have done so. Some of these scholars have pointed out that student-athletes in revenue sports should be viewed as employees under the right-of-control test. In addition, they point out that, in practice, the academic studies of these athletes take a back seat to their university's primary agenda of increasing its revenue and providing more exposure for the institution. As a

\footnotetext{
173 Section 117 of the IRC allows a student pursuing a degree to exclude any amounts of a qualified scholarship from their gross income. This includes amounts spent for tuition, fees, books, and supplies. For a recent articles discussing this issue, see Kathryn Kisska-Schulze and Adam Epstein, Northwestern, O'Bannon and the Future: Cultivating a New Era for Taxing Qualified Scholarships, 49 Akron L. Rev. 771 (2016), and Patrick Michael Tutka and Dylan Williams, The Expensive Truth: The Possible Tax Implications Related to Scholarship and Cost of Attendance Payments for Athletes 27, J. Legal AsPects AND SPORT 145 (2017).

174 Even though IRS rules make the portion of an athletic scholarship that covers room and board taxable, this is normally not enforced.

17526 C.F.R. § 1.117-4(c).

176 Revenue Ruling 77-263.

177468 U.S. 85 (1984).
} 
result, the rationale of Revenue Ruling 77-263 no longer applies, and the current athletic scholarships provided to athletes in revenue sports should be viewed as taxable income to the athletes up to the fair market value of their services. ${ }^{178}$ Regardless of whether this position currently has merit, compensating students beyond the cost of attendance could lead the IRS to take another look at the entire compensation issue of college athletes. Providing athletes in revenue sports with compensation beyond the cost of attendance strengthens the argument that the characterization of the compensation provided athletes has changed from university and student-athlete to that of employer/employee. Thus, if colleges and universities started to pay their athletes beyond the cost of attendance, the IRS might conclude that an athletic scholarship is part of a larger employee compensation package, and, thus, the amount up to the fair market value of the athlete's services should be subject to federal income tax. ${ }^{179}$ Such a change would also have implications for state and local income taxes as well.

\section{Other Consequences if Student-Athletes are Viewed as Employees}

Student-athletes are not viewed as employees under the various legal regimes that otherwise apply to the employer/employee relationship. As Matt Mitten, the executive director of the National Sports Law Institute at Marquette Law School, pointed out, if college athletes are paid "they would likely be characterized as employees. And that has a number of implications." 180 Thus, if colleges and universities start to pay athletes funds beyond cost of attendance, the notion that they are student-athletes, and not employees, might change under a number of legal schemes.

Scholarship funds paid to employees are currently not subject to the Federal Insurance Contributions Act ("FICA"). Under FICA, wages paid by employers to employees and received by employees from an employer are both subject to a tax rate of $7.65 \%$ for both the employer and employee (or a combined rate of $15.3 \%$ ), up to a $\$ 132,900$ for $2019 .{ }^{181}$ These funds are used to cover social security payments and Medicare health coverage primarily for the elderly. Section 3121(b) (10) of the IRC excludes wages paid by a university to a student enrolled and regularly attending classes for taxes under FICA. ${ }^{182}$ Treasury Department regulations, however, do not allow this exclusion if a student is considered a full-time employee with a normal work schedule over 40 hours. In a 2011 opinion, the

\footnotetext{
178 Patrick Michael Tutka and Dylan Williams, The Expensive Truth: The Possible Tax Implications Related to Scholarship and Cost of Attendance Payments for Athletes, 27 J. LEGAL AsPeCTS AND SPORT 145, 151-2 (2017).

179 Kathryn Kisska-Schulze and Adam Epstein, Northwestern, O'Bannon and the Future: Cultivating a New Era for Taxing Qualied Scholarships 49 Akron L. Rev. 771, 809 (2016).

180 Ivan Maisel, Paying Players Might Create Havoc, ESPN (July 15, 2011), http://www.espn.com/ college-sports/story//id/6768571/legal-issues-arise-paying-student-athletes (last visited Feb. 3, 2018).

181 There are two components to the FICA contributions, $6.2 \%$ for social security and $1.45 \%$ for Medicare premiums. While there is no income limit for the calculation of Medicare premiums, there is a limit of $\$ 132,900$ in 2019 for social security contributions.
}

18226 U.S.C. $\S 3121($ b)(10) (2012). 
Supreme Court held that this regulation meant that medical students enrolled in residency programs do not qualify for the exclusion. ${ }^{183}$ In theory, the NCAA rules limit the amount of time athletes can spend on their sport to 20 hours per week. But, the rules also allow for "voluntary" workouts that do not count in the limit. These voluntary activities include travel, warm-ups, and extra practices. Thus, athletes frequently devote 40 hours or more to their sport each week. If student-athletes are paid amounts beyond cost of attendance, the IRS may re-examine its current position regarding these exclusions of funds received by athletes in revenue sports from their institutions.

There are several other potential legal issues involved if athletes become employees. If student-athletes are viewed as employees, then state workmen's compensation laws might apply. ${ }^{184}$ As former NCAA president Walter Byers pointed out in his book, Unsportmsanlike Conduct: Exploiting College Athletes, it was the fear of athletes becoming employees for purposes of workmen's compensation that prompted most of the colleges to unite and insist with one voice on the concept of the student-athlete and that college sports was for amateurs. ${ }^{185}$ If courts and state industrial commissions conclude that athletes in revenue sports are employees for purposes of workmen's compensation laws then colleges and universities would be required to provide athletes who are employees with certain benefits when they are "injured on the job." These benefits could include not only permanent disability payments, but also payment of long-term medical care for sports-related injuries.

Other issues to address if a plausible argument can be made that athletes are employees include whether the Federal Labor Standards Act ("FLSA") applies to members of FBS football and men's basketball teams. ${ }^{186}$ While a student-athlete receiving scholarships that cover even the grant-in-aid amounts would receive far more than minimum wage, what about the walk-on non-scholarship athletes on a revenue sports team? Does the fact that many of the non-scholarship athletes' teammates are being compensated beyond the cost of attendance convert these non-scholarship athletes into employees for FLSA purposes and, thus, eligible for minimum wage requirements for their athletic "work"? Through the legal doctrine of respondeat superior, colleges and universities could also become civilly liable for some of the tortious conduct of their athlete employees, including

\footnotetext{
183 Mayo Foundation for Medical Educ. and Research v. United States, 562 U.S. 44 (2011).

184 One of the concerns that led to the NCAA becoming more of an enforcement mechanism were cases that held student-athletes were employees under Workmen's Compensation statutes. See Univ. of Denver v. Nemeth, 257 P2d 423 (Colo. 1953) and Van Horn v. Indus. Accident Comm'n, 33 CAL. Rptr. 169 (Cal. Ct. App. 1963).

185 Walter Byers, Unsportsmanlike Conduct: Exploiting College Athletes 69 (1995).

186 Berger v. NCAA, 843 F.3d 285 (7th Cir. 2016) (rejecting claim by University of Pennsylvania women's track and field athletes that FLSA applies to them). But see id. at 294 (Hamilton, J. concurring) ("I am less confident, however, that our reasoning should extend to students who receive athletic scholarships to participate in so-called revenue sports like Division I men's basketball and FBS football.”). See also Dawson v. NCAA, 2016 WL 5405638 (N.D. Cal. Filed Sept. 26, 2016).
} 
outrageous conduct during sporting contests. ${ }^{187}$ This would increase the risk exposure of universities. Athletes who are considered employees and who play for public universities might gain certain due process rights to their continued membership on their respective team, and, possibly, playing time. ${ }^{188}$ Universities, as employers, might have to pay unemployment insurance taxes on the wages of their athletes-turned-employees.

Another significant legal hurdle to address if athletes in revenue sports are provided compensation beyond cost-of-attendance scholarships is Title IX. Title IX requires colleges and universities to provide equality between men's and women's athletic programs in proportion to their respective enrollments with respect to the number of opportunities provided to men and women, the overall quality of the programs, and the amount of scholarship aid awarded. ${ }^{189}$ The requirement of equity for both sexes in athletic programs will prevent colleges and universities from providing extra compensation in the form of athletic scholarships to just male student-athletes. ${ }^{190}$ However, at least one scholar argues that if member institutions treat their athletes as employees, then they would not have to pay female athletes the same as male athletes. ${ }^{191}$ Title IX's requirements prohibiting gender-based pay discrimination are generally interpreted as coextensive with the anti-discrimination provisions that appear in the Equal Pay Act of 1963 and the Civil Rights Act of 1964. Thus, disparate compensation of employees playing revenue sports and employees playing female sports might be permissible under Title IX as long as the employee athletes' job descriptions for the revenue sport team involves greater skill, effort, and responsibility than the female student-athletes' job descriptions. It is precisely this logic that, for

187 See Hanson v. Kynast 494 N.E.2d 1091 (Ohio 1993) (holding that university student, who received no scholarships or compensation, voluntarily became member of university lacrosse team, purchased his own equipment and received instructions from coach, but was not otherwise controlled by coach, was not agent of university so as to impose liability upon university, under doctrine of respondeat superior, for injuries inflicted by student upon player of opposing team). In contrast, see Manning v. Grimsley 643 F.2d 20, 21-22 (1st Cir. 1981) (applying Massachusetts's vicarious liability law for employers to professional sports franchise) where the Baltimore Orioles were potentially liable for the actions of their employee pitcher who threw a baseball at a fan.

188 See, e.g., Hysaw v. Washburn Univ. of Topeka, 690 F. Supp. 940 (D. Kan. 1987).

189 See 34 C.F.R. $\$ \S 106.37$ (c), 106.41(c) (2018); A Policy Interpretation: Title IX And IntercolLegiate Athletics, 44 Fed. Reg. 71,413, 71,418 (Dec. 11, 1979).

190 See, e.g., Darren A. Heitner, Money and Sports: Economic Realities of Being an Athlete, DePaul J. Sports L. Contemp. Probs. 161, 166 (2012).

191 Marc Edelman, The Future of Amateurism After Antitrust Scrutiny: Why a Win for the Plaintiffs in the NCAA Student-Athlete Name \& Likeness Licensing Litigation Will Not Lead to the Demise Of College Sports, 92 Oregon L. Rev. 1019, 1051-2 (2014) (Title IX's requirements prohibiting gender-based pay discrimination are generally interpreted as coextensive with the antidiscrimination provisions that appear in the Equal Pay Act of 1963 and the Civil Rights Act of 1964. Thus, disparate compensation of male and female student-athletes would be permissible under Title IX of the Education Amendments of 1972 as long as the male student-athletes' job descriptions involved greater skill, effort, and responsibility than the female student-athletes' job descriptions.). 
example, allowed the University of Connecticut to enter into a contract valued at $\$ 13$ million with Geno Auriemma, the coach of its women's basketball team, and one valued at $\$ 17.9$ million for Kevin Ollie, the coach of the men's basketball team. ${ }^{192}$ Ollie's contract ran for five years starting June 1, 2016, and Aureimma's for five years starting in April 2016. As a result, the Title IX problem might be avoided by considering and treating the athletes in revenue sports as employees, but, as pointed out, this raises other issues regarding what happens when the athletes are considered employees. At any rate, the Title IX issue is one of the significant obstacles that will have to be addressed before a plan to compensate athletes beyond cost-of-attendance scholarships is put in place.

\section{F. Conclusion}

There is still more room within the amateur/education model for institutions to improve the situation of athletes in revenue sports. For example, not all institutions provide their athletes with multi-year and full cost-of-attendance scholarships. Also, in June 2014, Indiana University athletic director Fred Glass announced an athletic bill of rights for Indiana's athletes. Among the rights specified for athletes is a lifetime degree commitment. Accordingly, Indiana University will pay the cost of tuition for any athlete who wants to return to the university to purse an undergraduate degree if they did not obtain one while participating as a student-athlete. ${ }^{193}$ The university also allows the athlete to choose any course of study, major, or degree, with corresponding academic support services. ${ }^{194}$ These guarantees are improvements in the academic situation of athletes in revenue sports, but still within the amateur/education model. Another improvement in the situation of athletes is suggested by the statute recently adopted by the State of Nebraska. The statute has established an administrative system for providing medical and disability benefits to injured university athletes. ${ }^{195}$

Nevertheless, what this demonstrates is that the criticisms of racial exploitation of athletes participating in revenue sports has existed for a very long time. And the NCAA and its member institutions, sometimes responding to public criticism, sometimes under the threat of litigation, and sometimes based on their own initiatives, have made strides toward achieving the maximum compensation allowable for student-athletes in revenue sports under the amateur/education model. It is also clear that these measures have had a positive impact on the academic achievement of black male athletes in revenue sports. However, the question remains, will maximizing the benefits of the athletes under the amateur/ education model be enough to rebut the criticisms of racial exploitation of the current system, especially as revenues continue to climb?

\footnotetext{
192 Paul Dolye, Auriemma, Ollie Under Contract at UConn Through 2021 for Close to \$31M, HARTFORd Courant (Mar. 10, 2017), https://www.courant.com/sports/uconn-womens-basketball/ hc-uconn-basketball-coaches-contracts-0310-20170309-story.html.

193 See Student-Athlete Bill of Rights, Indiana University, http://iuhoosiers.com/documents/2015/5/21/genrel_2013_14_misc_non_event_BillOfRights.pdf.

194 Id.

195 See Neb. Rev. Stat. \$85-106.5 (2016).
} 


\section{Critical Race Theory Perspective on the Amateur/Education Model}

Often, the charge of racial discrimination or racial exploitation conflates two different concepts into a single misguided analysis. One form of racism understands that individuals act for many different reasons, but it is only when their actions are primarily motivated by a conscious desire to discriminate against someone because they are a member of a racial or ethnic group that racism exists. The second form of racial discrimination focuses on the discriminatory effects of given actions, policies, or procedures and is drawn from the recognition that our society is composed of various racial and ethnic groups who live in very different socio-economic conditions. The cause of these discriminatory effects could be conscious racial discrimination, but could also result from unconscious racism, the use of stereotypes, or institutional racism. When the charge is raised that athletes in revenue sports are racially exploited, it is the latter concept of discrimination that a person is asserting. The first section here will discuss these two different concepts of racial discrimination. The second section will briefly discuss the nature of the African-American experience that produced a collective group whose individual experiences are connected to those of the entire group and who are committed to an epic struggle against their continued oppression. Considering the connected nature of the African-American experience in the U.S., the actions and the images of black male athletes in revenue sports will impact the experiences of all blacks. The third section will examine how media images of black males in revenue sports helps to sustain some of the most harmful negative stereotypes that blacks encounter.

\section{A. Two Types of Racial Discrimination}

Despite the declaration of many pundits that the U.S. has already become a postracial society, ${ }^{196}$ there are still huge racial and ethnic disparities in important socioeconomic conditions. The median household income of blacks in 2016 was $\$ 39,490$, which was only $60.7 \%$ of white family income and $48.5 \%$ of Asian family income. ${ }^{197}$ With respect to per capita earnings, the figure for blacks of $\$ 22,861$ was only $65 \%$ of white and $63 \%$ of Asian per capita income. ${ }^{198}$ The 2016

\footnotetext{
196 See, e.g., Peter Wallsten, Election 2008: The Presidential Vote/News Analysis, L.A. Times (Nov. 5, 2008), at 11; Craig Gordon, Analysis: How Obama Won It, Newsday (Nov. 5, 2008), at W04; Kevin Sack, After Decades, a Time to Reap, N. Y. Times (Nov. 5, 2008), at A1; John B. Judis, It's A Wrap: The 2008 Campaign, L. A. Times (Nov. 9, 2008), at 34.

197 Black family income was also less than that of Hispanic household income $(\$ 47,675)$. In contrast, white non-Hispanic household income was $\$ 65,041$ and Asian household income was \$81,431. Income, Poverty, and Health Insurance Cover in the United States: 2016, U.S. CENsus BuREAU (Sept. 12, 2017), https://www.census.gov/newsroom/press-releases/2017/income-povery.html.

198 Historical Income Tables: People, U.S. Census Bureau tbl.P-1, https://www.census.gov/

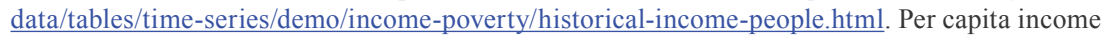
for blacks is actually higher than the per capita income of Hispanics of $\$ 20,430$. The per capita income for whites is $\$ 35,168$. For Asians, it is $\$ 36,309$.
} 
unemployment rates for blacks (8.4\%) was more than twice that of Asians $(3.6 \%)$, nearly twice that of whites (4.3\%), and significantly higher than that of Hispanics $(4.7 \%) .{ }^{199} \mathrm{~A}$ much larger percentage of blacks also live in poverty. The poverty rate in the Black Community stands at $27.2 \%$, in contrast to Hispanics at $25.6 \%$, Asians at $11.7 \%$, and whites at $9.9 \%{ }^{200}$ The disparities in poverty rates are even higher for blacks under the age of 18 . Over a third of black children, 36.7\%, live below the poverty line, in contrast to Hispanics at $33.8 \%$, whites at $18.5 \%$, and Asians at $13.8 \%{ }^{201}$ Beyond racial differences in income levels, black families also have considerably less accumulated wealth than white families. According to a September 2017 report issued by Prosperity Now and the Institute for Policy Studies, in 2016 the average white family possessed $\$ 134,000$ in wealth, compared to $\$ 11,000$ for the average black family. ${ }^{202}$ Thus, the average white family was more than 12 times wealthier than the average black family. While blacks with college degrees have more net worth, the wealth gap is considerably greater and the ratio is about the same. According to a 2016 report on educational attainment, the wealth gap between blacks and whites over the age of 25 with college degrees has remained stable for decades. ${ }^{203}$ In fact, "[w] hite households headed by someone with a college degree have a median wealth of $\$ 301,300$ compared to collegeeducated black households, which have a median wealth of $\$ 26,300 . " 204$

In a groundbreaking 40-year-old article, Alan Freeman introduced two different conceptions of racial discrimination. ${ }^{205}$ Freeman's article argued that the distinction between defining discrimination in terms of the intent of the actor, as opposed to effects of the actions, represents a distinction between the perpetrator's perspective of discrimination as opposed to the victim's perspective. As Freeman noted in his article, from the perpetrator's perspective, racial discrimination is aberrational and the product of irrational actors who stubbornly refuse to acknowledge the individuality of others. The goal of a struggle against racism

199 BLS Reports Report 1044 Labor Force Characteristics by Race and Ethnicity, 2016, U.S. BuREAU OF LABOR STATISTiCs fig.4 (2017), https://www.bls.gov/opub/reports/race-and-ethnicity/2016/ home.htm.

200 Poverty Status of People, by Age, Race, and Hispanic Origin: 1959 to 2016, U.S. CEnsus BuREAU tbl.3, https://www.census.gov/data/tables/time-series/demo/income-poverty/historical-poverty-people.html.

201 Poverty Status of People by Family Relationship, Race, and Hispanic Origin: 1959 to 2016, U.S. Census Bureau tbl.2, https://www.census.gov/data/tables/time-series/demo/income-poverty/ historical-poverty-people.html.

202 Prosperity Now and the Institute for Policy Studies, The Road to Zero Wealth (2017), https://prosperitynow.org/files/PDFs/road to zero_wealth.pdf.

203 Camille L. Ryan and Kurt Bauman, U.S. Census Bureau, Educational Attainment in THE United STATES: 2015 (2016), https://www.census.gov/content/dam/Census/library/publications/2016/demo/p20-578.pdf.

204 Tanzine Vega, Blacks Still Far Behind Whites in Wealth and Income, CNN Money (June 27, 2017), http://money.cnn.com/2016/06/27/news/economy/racial-wealth-gap-blacks-whites/index. html.

205 Alan Freeman, Legitimizing Racial Discrimination through Antidiscrimination Law: A Critical Review of Supreme Court Doctrine, 62 Minn. L. Rev. 1049 (1978). 
from this perspective is to stop bad actors from taking actions motivated by racial animus. From the victim's perspective, racism is ubiquitous throughout society because racial disparities in significant socio-economic conditions exist in the most important determinants of human flourishing. It is important to realize that the victim in the context of determining whether the amateur/education model is racially exploitive is the entire Black Community - not just a collection of individual blacks who are recruited because they have special athletic abilities.

From the perspective of the perpetrator, racism is viewed as generally aberrational and isolated. Thus, racial and ethnic statistics are of little use in determining its existence. For victims of racial discrimination, however, the elimination of racism and racial discrimination is accompanied by significant improvements in socio-economic conditions of life that were associated with racial discrimination. These changes include better employment opportunities, more income, less poverty, more wealth, and greater educational attainment. Thus, the racial disparities noted in important socio-economic conditions represent ways in which to measure the continued influence of racial discrimination.

If discriminatory intent is used as the definition of racial discrimination or racial exploitation, then it is obvious that the NCAA's rules governing amateurism are not discriminatory. Few, if any, commentators or legal scholars would argue that the NCAA adopted or maintains its rules and regulations embracing the principal of amateurism as a result of a conscious desire to discriminate against athletes who happen to be black males.

When commentators are implying that the NCAA's embrace of amateurism for revenue sports is racially discriminatory or racially exploitive, they have to have in mind a different concept of racism than discriminatory intent. That concept must look beyond the intent of the NCAA and its member institutions to the effects of the application of the principal of amateurism on blacks. However, once we start to focus on the effects of amateurisms, the focus should no longer be limited to just the interest of a few elite black athletes in FBS football or men's basketball. Rather, the consideration should be about the interest of the entire Black Community. For instance, there are about 432 four- or five-star high school recruits out of 300,000 who play high school football. ${ }^{206}$ From the standpoint of the Black Community, the focus is not just on the small number of four- and fivestar recruits but all of those high school students in the Black Community who play football. More importantly, however, this new point of view suggests that there are plenty of other measures that the NCAA and its member institutions could institute to assist the Black Community in increasing college attendance and graduation rates that would help to rebut any assertion that the application of the amateur/education model to revenue sports is racially discriminatory.

\footnotetext{
206 Alex Kirshner, This Is How Rare It Is to Be a Blue-chip College Football Recruit, SB NATION (Jan. 26, 2018), https:/www.sbnation.com/college-football-recruiting/2016/2/2/10879624/recruiting-stars-rankings-high-school-football.
} 


\section{B. The Nature of the African-American Experience in the United States}

The central feature of the African-American experience in the United States is the treatment of a group of individuals classified by their race as involuntary members of a historically oppressed racial group. As noted black scholar W.E.B. DuBois summarized it, "The So called Negro group ... while it is in no sense absolutely set off physically from its fellow Americans, has nevertheless a strong, hereditary cultural unity born of slavery, common suffering, prolonged proscription, and curtailment of political and civil rights. ... Prolonged policies of segregation and discrimination have involuntarily welded the mass almost into a nation within a nation." 207

Race continues to be the dominant feature of the present and past experiences of African-Americans in the United States. The experience, however, has two different aspects. One aspect involved what it means to be a victim of racial discrimination. With regard to the descendants of the soil of Africa, for much of America's history, dominant American culture was deeply invested in notions of white (or at least Anglo-Saxon and Teutonic) superiority. Thus, dominant American cultural attitudes had clear concepts of what it meant to be black and imposed those notions on dark-skinned people. Black people have long been negatively stereotyped. For example, the first edition of the Encyclopedia Britannica published in 1798 stated that black people are prone to "idleness, treachery, revenge, cruelty, impudence, stealing, lying, debauchery, nastiness and intemperance." ${ }^{208}$ Within this aspect of the experience of being black, African-Americans are viewed as passive objects completely subjected to domination, rather than as people with their own wills, hopes, and desires, who influence their own destiny. Because this aspect presupposed that blacks were inferior or substandard in some important way to whites, it obscured the basic injustice of the discriminatory treatment that blacks experienced throughout American history. Instead, the belief in the inferiority of blacks made their subjugation appear as the result of the natural order of things. Thus, one aspect of the experience of historical discrimination is the experience of what it means to be "raced" or branded as inferior. ${ }^{209}$

Against the background of racial domination, however, the descendants of the sons and daughters of the soil of Africa in the U.S. developed a counter-discourse to how mainstream American society viewed and treated them, the central feature of which was the collective struggle against their racial oppression. As

\footnotetext{
207 W.E.B. DuBois, Three Centuries of Discrimination, THE CRIsIs 54, 362-63 (1947).

208 The first edition of the Encyclopedia Britannica in 1798 used this to define "Negroes." See Kevin Brown, Race, Law and Education in the Post-Desegregation Era 66 (2005).

209 See, e.g., Kendall Thomas, Comment, Frontiers of Legal Thought Conference, Duke Law School (Jan. 26, 1990), quoted in Charles R. Lawrence III, If He Hollers Let Him Go: Regulating Racist Speech on Campus, 1990 Duke L. J. 431, in Mari J. Matsuda, Charles R. Lawrence III, Richard Delgado and Kimberlé W. Crenshaw, Words That Wound 53, 61 (1993); see also D. Marvin Jones, Darkness Made Visible: Law, Metaphor, and the Racial Self, 82 Geo. L. J. 437 (1993) (arguing that racial categories are neither objective nor natural, but ideological and constructed. In these terms race is not so much a category but a practice: people are raced).
} 
James Forman stated about this aspect of the African-American experience, "our basic history is one of resistance." ${ }^{210}$ Commenting on this, Mari Matsuda noted that "Black Americans, the paradigmatic victim group of our history, have turned the Bible and the Constitution into texts of liberation." 211 From the perspective of the counter-discourse, blacks are not viewed as inferior, but as oppressed. Thus, in contrast to the "raced" aspect of the historical experience of blacks was the active experience of a group who did not control the visible reins of power, but still served as the architects of their own struggles against their oppression. This struggle against oppression was limited by and responsive to the conditions imposed on blacks by the dominant community. Nevertheless, this commitment to the struggle against racial oppression and its concomitant sacrifice of the interest of the individual for the advancement of the Black Community is as much a part of the historical experience of blacks in the U.S. as the experience of being victims of racial oppression.

There are many historical examples of the sacrifice of members of the Black Community for the betterment of the entire Community. In fact, major advances of the Black Community tend to result only from huge sacrifices of thousands of individual blacks. One example is the remarkable efforts of black people to free themselves during the Civil War. Official statistics show that almost 179,000 black soldiers served in the Union army, 7,122 of whom were officers. ${ }^{212}$ By the end of the Civil War, African-Americans comprised 10\% of the Union's armed forces. An additional 29,000 blacks served as sailors, comprising 25\% of Union seamen. ${ }^{213}$ The black troops also paid a heavy price during the Civil War that led to the abolition of slavery, suffering a disproportionately large number of casualties. Approximately 37,300 blacks died during the conflict, amounting to more than $10 \%$ of the Union war deaths. ${ }^{214}$ President Abraham Lincoln often emphasized the significance of the black soldiers to the Union's war effort. Lincoln candidly noted that without the black troops, no administration could have saved the Union. ${ }^{215}$ However, the black troops were not fighting in the Civil War just to preserve the Union. They were fighting to liberate the entire Black Community from slavery. Their sacrifice is better explained as part of a collective effort to free their people than to assure that the Union was perpetual.

During America's long years of fighting against legally entrenched segregation of America's public schools, the interests of many individuals in the Black

\footnotetext{
210 See Stephen Tuck, We Ain't What We Ought to Be: The Black Freedom Struggle From Emancipation to OBama 2 (2010).

211 Mari Matsuda, Looking to the Bottom: Critical Legal Studies and Reparations, 22 HARv. C.R.C.L. L. Rev. 323, 335 (1987).

212 James M. McPherson, The Negro’s Civil War: How American Blacks Felt \& Acted During THE War For the Union 241 (1991).

213 Maulana Karenga, Introduction to Black Studies 144 (2d ed. 1993).

214 McPherson, supra note 213.

215 See Letter to Charles D. Robinson, August 17, 1864, in The Collected Works of Abraham LinCOLN 499-501 (Ed. Roy P. Basler 1953).
} 
Community were sacrificed. For example, between 1954 and 1972, more than 70,000 black teachers lost their jobs in the Southern and Border States. ${ }^{216}$ Also, $96 \%$ of the African-American principals lost their jobs due to racial integration in North Carolina, 90\% in Kentucky and Arkansas, 80\% in Alabama, 78\% in Virginia, and $77 \%$ in South Carolina and Tennessee. ${ }^{217}$ Beyond the sacrifices of black teachers and administrators were the sacrifices of black elementary and secondary students whose education was completely disrupted by the efforts to desegregate American public education. ${ }^{218}$

To draw a closer analogy to elite black male athletes in revenue sports, we could consider the impact of affirmative action policies at selective colleges and universities. We often hear assertions that certain blacks who would be admitted into selective higher education programs without the benefit of affirmative action are having their academic accomplishments devalued by these programs. ${ }^{219}$ This position is visible in the comments made in December 2015 by the late Supreme Court Justice Antonio Scalia during oral arguments for the last affirmative action decision of the Court in which he participated. Justice Scalia suggested that African-American students on affirmative action would do better if they attended "a less-advanced school, a less-a slower-track school where they do well.".220 For the ones who were not on affirmative action, their accomplishments were being tainted by their "less qualified" brethren. Yet, the history of affirmative action measures is that they have significantly increased the number of black lawyers, doctors, business executives, and other professionals. Thus, regardless of whether a few blacks have been harmed by affirmative action, the program has been significant in helping to create tens of thousands of black lawyers, doctors, dentists, college professors, and business executives.

\footnotetext{
216 See Samuel B. Etheridge, Impact of the 1954 Brown v. Topeka Board of Education Decision on Black Educators, 30 The Negro Educ. Rev. 213, 223-4 (1979). Another source put the number at more than 31,000 in Southern and Border States. Smith and Smith, Desegregation in the South and the Demise of the Black Educator, 20 J. Soc. \& BeHAv. ScI. $28-40$ (1974).

217 Displacement and Present Status of Black School Principals in Desegregated School Districts: Hearings before the U.S. Senate Select Committee on Equal Educational Opportunity, 92d Cong., 1st Sess. (1971) (statement of Benjamin Epstein). In addition, Epstein also testified that $50 \%$ of the African-American principals lost their jobs in Georgia and 30\% did so in Maryland. Id.

218 For example, on Prince Edward County, Virginia, many black school children went without education for five years, as part of the effort to compel the integration of the public schools there. The Little Rock Nine that integrated Little Rock's Central High School received a rude introduction when they enrolled in the high school. And black students seeking to desegregate public schools encountered this rude experience all over the country. Also, black students disproportionately started their school days earlier and ended them later than their white counterparts because they bore the brunt of school bussing for the purpose of desegregation. See Kevin Brown, RaCE, Law And Education In The Post-Desegregation Era: Four Perspectives On Desegregation And RESEGREGATION 167-174 (2005).

219 See, e.g., Stephen Carter, Reflections Of An Affirmative Action Baby (1991).

220 See, e.g., Yanan Wang, Morning Mix Where Justice Scalia Got the Idea That African Americans Might Be Better Off at 'Slower-Track' Universities, WASH. (Dec. 10, 2015), https://www. washingtonpost.com/news/morning-mix/wp/2015/12/10/where-justice-scalias-got-the-idea-thatafrican-americans-might-be-better-off-at-slower-track-universities/ (last visited Feb. 3, 2018).
} 


\section{Impact of Stereotypical Images of Black Male Athletes on the Black Community}

Stereotypes of groups are the product of consistent association of its members with specific traits. The mass media helps to create and perpetuate these stereotypes; thus, media images of blacks can influence perceptions of the American public of all black people. ${ }^{221}$ As the NCAA said in the first sentence of its opening statement in Alston v. NCAA case, "College football and basketball are part of the fabric of American life. These sports are wildly popular, enjoyed by millions." ${ }^{222}$ Since sports permeates American culture, especially FBS football and men's basketball, the American public is often exposed to images of black sports figures. For example, while the television audience for the January 7, 2019, College Football Playoff national championship game on ESPN, in which Clemson blew out Alabama 44-16, was its lowest in the five years of the game, some 25.2 million people watched it. ${ }^{223}$ And even though the viewership for the 2018 NCAA men's basketball championship game between Michigan and Villanova saw a 28\% dip from the 2017 game, the game averaged 16.5 million viewers. ${ }^{224}$

Black athletes playing revenue sports are inherently connected to the Black Community; and their conduct both benefits and disadvantages other blacks in numerous ways. As one researcher put it, media images of sports "have played a central role in biologising black performance via their constant use of animalistic similes to describe black athletes." 225 Among the most destructive racial stereotypes of black males that sports images reinforce are that they may be physically gifted, but are lacking the necessary mental skills and intelligence needed for elite

\footnotetext{
221 See, e.g., Psychological Reactions to Crime News Portrayals of Black Criminals: Understanding the Moderating Roles of Prior News Viewing and Stereotype Endorsement. Communication Monographs, 73, 162-187; Black Criminals and White Officers: The Effects of Racially Misrepresenting Law Breakers and Law Defenders on Television News. Media Psychology, 10, 270-291; Dana Mastro (2009), Effects of Racial and Ethnic Stereotyping. In J. Bryant and M. B. Oliver (Eds.), Media Effects: Advances in Theory and Research (3rd ed., pp. 325-341). New York, NY: Routledge; Dana Mastro and Maria Kopacz (2006), Media Representations of Race, Prototypicality, and Policy Reasoning: An Application of Self-Categorization Theory. Journal of BroAdCASTing \& Electronic Media, 50, 305-322.

222 See In Re National Collegiate Athletic Association Athletic Grant-In-Aid Cap Antitrust Litigation, Case 4:14-md-02541-CW Document 993 Filed 08/27/18 Page 4 of 59

223 Ralph D. Russo, Clemson Blowout Draws Lowest TV Ratings for a CFP Title Game, WASHINGTON Post (Jan. 8, 2019) https://www.washingtonpost.com/sports/colleges/clemson-blowout-drawslowest-tv-ratings-for-cfp-title-game/2019/01/08/26d2c4c2-136d-11e9-ab79-30cd4f7926f2 story. html?utm term $=.1313 \mathrm{f} 2666327$.

224 Joe Otterson, NCAA Championship Game Viewership Drops 28\% From 2017, VARIETY (Apr. 3, 2018) https://variety.com/2018/tv/news/2018-ncaa-championship-game-ratings-1202742895/.

225 Ben Carrington, Fear of a Black Athlete: Masculinity, Politics and the Body, New Formations, 45, 91-110 (2001/2).
} 
occupations. ${ }^{226}$ Studies point to the fact that televised male sports promote these stereotypical and common sense notions of black males. For example, according to Lapchick's 2017 Racial and Gender Report Card: College Sports, 75\% of men's basketball and $86.9 \%$ of football head coaches in Division I were white. ${ }^{227}$ Thus, as America watches college football or basketbal games, it is often introduced to the specter of a football team on the field or basketball team on the court where a majority of the players are black, but the person in charge of the intellectual aspect of the game is white. ${ }^{228}$ Given the over-representation of black athletes in revenue sports, the paucity of black head coaches in FBS football and men's basketball reaffirms the notion that blacks are not as intelligent.

One of the most destructive stereotypes of blacks, particularly males, is that that they are aggressive, dangerous predators, and prone to violence. As law professor Frank Cooper illuminated, there is a longstanding cultural image of black men that includes the "Bad Black Man." ${ }^{229}$ It is an image that existed during slavery in the image of the black men as beasts of the field. Black men of all classes have been victimized by these stereotypes. ${ }^{230}$ Several studies have found that the representations of black athletes reinforce this view of black males. ${ }^{231}$ Because of their fame and popularity, the off-field activities of athletes in revenue sports receives substantial media coverage. Much of America is treated to images of black college players engaged in violent and criminal acts, like Florida State quarterback De'Andre Johnson and University of Oklahoma running back Joe Mixon punching their girlfriends, or other well-known college star athletes suspected of criminal activities like Lawrence Phillips, Maurice Clarett, and Darrell Williams. An ESPN Outside the Lines story in 2015 discussed the results of a study that examined more than 2,000 documents related to criminal activity of basketball and football players at 10 universities with major collegiate sports programs (Auburn, Florida, Florida State, Michigan State, Missouri, Notre Dame, Oklahoma State, Oregon State, Texas A\&M, and Wisconsin). According

\footnotetext{
226 Harry Edwards, The Black “Dumb Jock”: An American Sports Tragedy, College Board Rev., N131, 8-13 (Spr. 1984). For a listing of this literature see Andrew Grainger, Joshua I. Newman, and David L. Andrews, Sport, the Media, and the Construction of Race in HandBook of SporTs AND Media 452 (2006).

227 See Richard Lapchick Et A1., Univ. Cent. Of Fla. Inst. for Diversity And Ethics in Sport, The 2017 Racial And Gender Report Card: College Sport 2 (2017), http:// nebula.wsimg.com/5665825afd75728dc0c45b52ae6c412d?AccessKeyId=DAC3A56D8FB782449D2A\&disposition=0\&alloworigin=1.

228 Only 7.6\% of the head coaches in Division I football were African-Americans in 2016-17 and African-Americans held only $22.3 \%$ of head coaching positions in men's basketball. Id.

229 See generally Frank Rudy Cooper, Against Bipolar Black Masculinity: Intersectionality, Assimilation, Identity Performance, and Hierarchy, 39 U.C. DAvis L. Rev. 853, 857-58 (2006).

230 Consider, for example, the arrest of African-American Harvard professor Henry Louis Gates, Jr. while he attempted to open his front door. Krissah Thompson, Arrest of Harvard's Henry Louis Gates Jr. Was Avoidable, Report Says, WAsh. Post (June 30, 2010), http://www.washingtonpost. com/wp-dyn/content/article/2010/06/30/AR2010063001356.html.

231 For a listing of this literature, see Sport, the Media, and the Construction of Race in HANDBOOK OF SPORTS AND 454 (2006).
} 
to their story, in half the programs at least $15 \%$ of the athletes were involved in some kind of criminal activity. ${ }^{232}$

Elite athletes in college sports are also often portrayed as self-centered, arrogant, mercenary, deviant, drug abusers, and generally misbehaving. Beyond the off-field activities, football and basketball, but especially football, are violent games. Football is a "combat sport" centered on high levels of aggression and violence. Injuries in the sport are not so much accidents or violations, but incorporated as part of the game. ${ }^{233}$ Thus, just watching college football exposes Americans on a weekly basis every autumn to images of black males engaged in a very violent activity. These views of black males on the sports field provide constant fuel to sustain the stereotype that black athletes are naturally threatening and prone to violent conduct. ${ }^{234}$

The aforementioned discussion is not intended to cast blame of black male athletes in revenue sports. The point is to make the connection between them and our society's negative impressions of blacks. Such media attention of black male athletes contributes to negative stereotypes of black people, especially black males. As Blackstone has noted, "there is a connection between black male sports athletes and the American stereotypical image that black males are threatening characters." Another commentator stated, "Unfortunately, the sports media has perpetuated an image of African American athletes as dangerous criminals. This image has been fashioned through the media's racialized reporting of athlete crime, and the media's portrayal of African American athletes as bestial, intellectually inferior, beings." 235

One place where our society's images of black males as prone to aggressive and criminal behavior manifests itself is in the mass incarceration of black males in America's jails and prisons. As college sports gained in popularity, the number of black males entangled with the criminal justice system exploded. Due in no small part to the War on Drugs, between 1980 and 2013, the combined U.S. prison population in state and federal institutions increased five times from about 300,000 to more than 1.5 million. ${ }^{236}$ According to the U.S. Bureau of Justice in 2014, about 539,500 blacks in the U.S. were in either state or federal prisons. They made up approximately $35.7 \%$ of all prisoners. When you add that to the 263,800

\footnotetext{
232 Two decades ago, a study showed that $20 \%$ of the members of the NFL had been charged with a serious crime. See Jeff Benedict and Don Yaeger, Pros and Cons: The Criminals Who Play The NFL (1998). See also, David Leonard, A World of Criminals or a Media Construction? Race, Gender, Celebrity, and the Athlete/Criminal Discourse in Handbook Of Sports And Media 524 (2006).

233 Michael Messner, When Bodies are Weapons: Masculinity and Violence in Sport, 25 InTERNAtional Review for the Sociology of Sport 203-220 (1990).

234 For a listing of this literature, see Andrew Grainger, Joshua I. Newman, David L. Andrews, and David Leonard, A World of Criminals or a Media Construction? Race, Gender, Celebrity, and the Athlete/Criminal Discourse in Handbook Of Sports And Media 454 (2006).

235 Jake James Cullen Evans, A Criminal Justice System Without Justice: The News Media, Sports Media, \& Rap's Influence on Racial Crime Disparities, 5 Univ. Miami Race \& Social Justice Rev. 117, 123 (2015)

236 Michelle Alexander, The New Jim Crow 6 (2014); see generally E. Ann Carson, U.S. DeP't of Justice, Prisoners in 20131 (2014), http://www.bjs.gov/content/pub/pdf/p13.pdf.
} 
blacks who on average are in local jails, there are over 800,000 blacks behind bars at any given time in the U.S. Estimates indicate that $32.2 \%$ of African-American males will spend part of their life in prison, versus $17.2 \%$ of Hispanic males and $5.9 \%$ of white males. Wisconsin sociology professor Pamela Oliver further points out that, "about a third of African American men are under the supervision of the criminal justice system, and about 12\% of African American men in their 20 s and 30 s are incarcerated." In fact, the U.S. imprisons a larger percentage of blacks than South Africa did during the height of apartheid. ${ }^{237}$

The performance of black male athletes in revenue-generating sports may have other less obvious effects on other blacks in the criminal justice system. A study by Louisiana State University ("LSU") economics professors Ozkan Eran and Naci Mocan looked at decisions rendered by judges that graduated from LSU in juvenile courts in Louisiana between 1996 and 2012. ${ }^{238}$ They found that when LSU won a football game it was supposed to win or lost a football game it was supposed to lose, there was no effect on the sentences that these judges meted out to black males. However, when LSU was upset, the judges imposed longer sentences on the black males who appeared in front of them the following week. It was as if the judges were taking some of their frustrations about the LSU football team out on black male adolescents in front of them. The study also found that an LSU upset win did not benefit black males who appeared in front of these judges.

\section{Programs and Policies to Help the Black Community}

As previously stated, the purpose of this article is to reformulate the debate about whether the amateur/education model applied to the revenue sports of FBS football and men's basketball is racially exploitive by focusing on the interest of the entire Black Community. In doing so, we will suggest that some of the revenues generated by FBS football and men's basketball be devoted to the funding and creation of programs that are directed toward increasing the college attendance and graduation rates of the Black Community. The primary reason to suggest that these programs focus on college attendance and participation rates is to take advantage of the existing educational expertise that the NCAA and its member institutions possess. While black male student-athletes often encounter negative stereotypes that view them as dumb jocks, these negative stereotypes also negatively impact the educational experiences of the black students on their campuses. ${ }^{239}$ Thus, it is likely that all the black students on the campuses of revenue sports programs have to fight the negative stereotypes that sports coverage contributes to perpetuating.

\footnotetext{
237 See, Ta-Nehisi Coates, Mapping the New Jim Crow, The Atrantic (Oct. 17, 2014) (quoting Michelle Alexander), https://www.theatlantic.com/politics/archive/2014/10/mapping-the-new-jimcrow/381617/.

238 Ozkan Eran and Naci Mocan, (2016). Emotional Judges and Unlucky Juveniles. NBER Working Paper 22611, https://www.nber.org/papers/w22611.

239 See, e.g., Shaun Harper, Black Male College Achievers and Resistant Responses to Racist Stereotypes at Predominantly White Colleges and Universities, 85 HARV. EDUC. REV. 614 (2015).
} 
There are other reasons that the programs and policies we suggest should focus on the college attendance and graduation rates of blacks. Substantial racial and ethnic gaps exist in terms of educational achievement in the U.S. A 2013 report by the National Center on Education Statistics noted that, for freshmen entering high school in 2006 and due to graduate in 2010, the number of students able to graduate in four years varied substantially for the different racial groups. Only $66.1 \%$ of blacks graduated in four years, compared with $69.1 \%$ for Native Americans, 71.4\% for Hispanic, 83.0\% for whites, and 93.5\% for Asians. ${ }^{240}$ According to a Pew Research Center report in 2014, while blacks made up $16 \%$ of high school graduates, they made up only $14 \%$ of students enrolled in college. But since blacks are much more likely to go to two-year and community colleges, they made up only $9 \%$ of those with bachelor degrees or higher. ${ }^{241}$ Also, the percentage of those with college degrees in 2017 varies substantially among the racial/ethnic groups. Thus, whereas $24.3 \%$ of blacks over the age of 25 have a college degree, $38.1 \%$ of whites and $55.4 \%$ of Asians have obtained such a degree. ${ }^{242}$ And these racial gaps in college attendance and obtaining degrees has persisted for many years. For example, in 1975, 6.4\% of blacks over the age of 25 had college degrees compared to $14.9 \%$ of whites. ${ }^{243}$

Blacks also tend to begin pursuing their higher educational credentials at a later date than members of other racial/ethnic groups. Whereas over $80 \%$ of Asians, whites, and Latinos start college at age 20 or younger, only $69 \%$ of blacks do. ${ }^{244}$ Additionally, only $38 \%$ of blacks who started college in 2010 completed a certificate or degree within six years, compared to $63.2 \%$ of Asians, $62 \%$ of whites, and $45.8 \%$ of Latinos. ${ }^{245}$ Blacks also tend to borrow more money to graduate with a bachelor's degree than any other group due to the lower levels of income and wealth in the Black Community. While only $14 \%$ of blacks have no student debt when they graduate with a bachelor's degree, almost a third of them have accrued more than $\$ 40,000$ in student debt. In contrast, the respective

\footnotetext{
240 Robert Stillwell and Jennifer Stable, U.S. Department Of Education, Public School Graduates And Dropouts From The Common Core Of Data: School Year 2009 -10: First Look (Provisional Data) 4 (2013). These high school graduation rates are based on receipt of a diploma. Therefore, they exclude from high school graduates those that only receive a certificate of completion or its equivalent.

241 Jens Manuel Krogstad and Richard Fry, More Hispanics, Blacks Enrolling in College, But Lag in Bachelor's Degrees, Pew Research Center: Fact Tank (Apr. 24, 2014), http://www.pewresearch.org/fact-tank/2014/04/24/more-hispanics-blacks-enrolling-in-college-but-lag-in-bachelorsdegrees/.

242 For Hispanic/Latinos, the percentage is only $17.2 \%$. See Digest of Educational Statistics, National Center for Educational Statistics, Rates of High School Completion and Bachelor's Degree Attainment Among Persons Age 25 and Over, by Race/Ethnicity and Sex: Selected Years, 1910 through 2017, Table 104.10, https://nces.ed.gov/programs/digest/d17/tables/dt17 104.10.asp

243 Id.

244 Doug Shapiro et al., Signature 12 Supplement: Completing Collegge: A National View of Student Attainment Rates by Race and Ethnicity 7 fig.3 (2017), https://nscresearchcenter.org/ wp-content/uploads/Signature12-RaceEthnicity.pdf.

${ }^{245}$ Id. at 10, fig.6.
} 
percentages for Asians are $43 \%$ and $7 \%$, for whites $32 \%$ and $16 \%$, and for Latinos $27 \%$ and $17 \%$. ${ }^{246}$ Financial difficulties help to explain why it often takes blacks longer to finish a college degree. Almost $30 \%$ of blacks take 10 years or longer, which is more than twice the percentage of Asians, 50\% more than whites, and more than Latinos. ${ }^{247}$

The urgency for devoting proceeds from revenue sports to increase the college participation and graduation rates of blacks may be even more important due to the changing nature of the black college athlete in these sports. Most Americans still have the vision of poor urban inner-city blacks dominating college football and basketball. However, the rising academic requirements of college sports and the need to enroll youngsters in specialized athletic programs well before the time they reach college may be having the effect of substantially reducing the percentage of first-generation and poor blacks who receive athletic scholarships. In an article titled, "The Gentrification of College Sports," Thomas Ferry reveals that starting in 2010, the NCAA began to ask college athletes whether they were first-generation college attendees as part of a little-known GOALS Study. The results of the study suggested that between 2010 and 2015, most sports are seeing a drop in first-generation athletes. As of 2015, the percentage of freshmen who were first-generation at all of the nation's four-year colleges was $17.2 \%$. In contrast, only $14.2 \%$ of all Division I athletes are first generation; the figure was 19\% for Division I basketball and $23 \%$ for FBS football. ${ }^{248}$ The figures for these two sports, however, are down nine percentage points and three percentage points, respectively, in five years. However, due to the concerns about the risk of CTE from playing football, it is likely that the percentage of low-income players will increase.

Further, increasing the college attendance and graduation rates of blacks would successfully combat the racial income and wealth gaps that exist in the U.S. The income gaps between those with college degrees compared to high school diplomas have grown substantially over the past 50 years. ${ }^{249}$ Ron Haskins at the Brookings Institute points out that college education is also the best hedge that America's poorest people have to break the cycle of poverty. For the children of those in the bottom quintile of income, if they finish college only $16 \%$ will end up in the bottom quintile, whereas if they do not $45 \%$ will. ${ }^{250}$

Among the programs that the NCAA and its member institutions could institute or fund are ones that could support the other non-athlete black students on their campuses. This realization has not gone unnoticed by commentators.

\footnotetext{
246 College Board, Trends in Student Aid 2015, 27 (2015), http://trends.collegeboard.org/sites/ default/files/trends-student-aid-web-final-508-2.pdf.

247 For Asians, 14\% take at least 10 years. For whites and Latinos, the comparison figures are $17 \%$ and $20 \%$, respectively. $I d$.

248 See Thomas Ferry, The Gentrification of College Sports, https://theundefeated.com/features/ gentrification-of-ncaa-division-1-college-basketball/.

249 Roy Haskins, Education and Economic Mobility, in Getting Ahead or Losing Ground: EconOmic Mobility In America (Eds. Julia B. Isaac, Isabel V. Sawhill, and Roy Haskins, 2008), http:// www.brookings.edu/ /media/research/files/reports/2008/2/economic-mobility-sawhill/02 economic mobility sawhill ch8.pdf.

${ }^{250}$ Id. at 5, fig. 6.
} 
Harper has called on colleges and universities to extend targeted academic advising, tutoring, clubs, and activities, like skills development resources, structured study spaces, alumni networks, and committed institutional agents, to black men who were not athletes in order to improve their academic success and college completion rates. ${ }^{251} \mathrm{He}$ also proposes that colleges and universities provide more financial aid to non-student-athlete black males in order to reduce the number of hours they have to work. Thus, he implies that among other ways the NCAA and its member institutions can respond to the charge of exploitation of black male athletes in revenue-generating sports is to provide more academic assistance to black male students who are not athletes at the universities.

Beyond instituting policies and programs to improve the graduation rates of blacks at Division I institutions, the NCAA and its member institutions could institute more pre-college programs in urban or rural school districts with large populations of black students. For example, the NCAA and its member institutions could establish or expand programs that provide SAT and ACT preparation courses in high schools with a high concentration of black students. They could provide college counselors or financial aid advisors who would help ensure that students are aware of the demands and expectations for college and the potential resources available for funding their education. The NCAA and its member institutions could create scholarship programs to assist students who enroll on their campuses after participating in an institution's pre-college program. These institutions could create or expand mentorship programs that connect students, staff, or faculty to pre-college students to provide those students with the encouragement, resources, and necessary know-how to navigate the college application process. In short, the types of programs can vary from institution to institution, but the common theme is to increase the number of blacks who are attending and graduating from Division I colleges and universities.

\section{Conclusion}

The amateur/education model provides an acceptable way to look at college sports from the perspective of all athletes playing college sports. However, its application to the primary revenue sports of FBS football and men's basketball may present another issue. Where the primary beneficiaries of non-revenue sports are the athletes who participate, the same cannot be said for revenue sports. For many of the Division I institutions with these sports, their income provides the necessary revenue to cover not only the scholarships for athletes in revenue sports, but to also cover the expenses of the entire athletic department, including those related to non-revenue sports. The funds produced by revenue sports also pays for the athletic facilities for their own sports, which increasingly include luxury boxes for cherished university officials and alums. Some colleges and universities even use monies generated by FBS football and men's basketball to subsidize general university expenses. As a result, the current structure of college sports that applies the amateur/education model to revenue sports has

251 HARPER, supra note 18 , at 16-17. 
created a situation where many other interested groups are profiting from the toil of these athletes.

The problematic nature of applying the amateur/education model to the revenue sports is exacerbated when we realize that the majority of elite athletes in FBS football and men's basketball are black males. Added to the concerns about whether the amateur/education model is suitable for revenue sports is the argument that its application is potentially racially exploitive because the interest of black male athletes are being sacrificed at the altar of their institutions for the benefit of so many others. For more than 30 years, commentators have pointed to the racial exploitation of college sports.

For those who support the application of the amateur/education model to revenue sports, they believe that if there are any inadequacies in the current system, they can be cured by the colleges doing more to improve the educational achievement of the student-athlete. The problem for this group is twofold. First, over the past 35 years, the NCAA and its member institutions have implemented numerous changes intending to improve the educational attainment of all athletes, especially black males in revenue sports. These measures have had their intended effects and have led to substantial improvements in the academic success of black males in revenue sports. Second, the revenues generated by college sports continues to increase. Thus, as colleges and universities are running out of room to substantially improve the academic performance of their black male athletes in revenue sports, the funds that those athletes generate continues to grow. Regardless of how you view the current system, what view will people have about it in another 10 to 20 years? Those who believe that the athletes should receive more compensation generally suggest that college sports abandon the amateur/education model. However, there are several legal obstacles involved with paying the athletes for playing their sport. Doing so could very well destroy college sports as we know it. This is the debate that has raged for more than 30 years. The common denominator of both sides is that they each view the issue with the assumption that the funds generated by revenue sports must be split only between the athletes or the NCAA and its member institutions.

To raise the question of whether the application of the amateur/education model to revenue sports is racially exploitive requires that we have a definition of racism. One form of racism defines it as when a person's actions are primarily motivated by a conscious desire to discriminate against someone because they are a member of a racial or ethnic group. This is the predominant legal definition of racism. Under this understanding, racism only exists when a person's actions are primarily motivated by discriminatory intent. The second form of racial discrimination focuses not on the motives of the actor, but the discriminatory effects of given actions, policies, or procedures. It is drawn from a recognition that due to our country's legacy of racial discrimination, we live in a society composed of various racial and ethnic groups who live in very different socio-economic conditions. The cause of these discriminatory effects could be conscious racial discrimination, but could also result from unconscious racism, the use of stereotypes, or institutional racism. When the charge of racial exploitation produced by the application of the amateur/education model to revenue sports is raised, it is the latter concept of discrimination that a person is asserting. But, once the focus 
is on discriminatory effect, the question is not limited to the impact on a few elite athletes playing revenue sports. Rather, in order to determine if the application of the amateur/education model has a discriminatory effect, we must consider its impact on the entire Black Community.

Ultimately, this article aims to redevelop the discussion about whether the amateur/education model applied to the revenue sports is racially exploitive by focusing on the interest of the entire Black Community. If we see the issue of racial exploitation in terms of the entire Black Community, then potential solutions to the current dilemma are not so limited. To counteract the notion that the amateur/education model is potentially racially exploitive, the NCAA and its member institutions could institute and fund programs that would increase the college attendance and graduation rates for all blacks. The programs that the NCAA and its member institutions could institute or fund can help not only blacks who are currently on the campuses of Division I schools, but also assist students in predominately black school districts throughout the country. These programs for high school and junior high schools students could include providing these students with access to college counselors and financial aid experts, SAT and ACT preparation courses, tutors in math and science, and establishing college mentor programs.

\section{Authors' Note}

We would like to acknowledge and express our appreciation to many colleagues and other friends whose support and suggestions have been so valuable to this article. Special thanks to professors Andr'e Douglas Pond Cummings, Luis Fuentes-Rowher, David Gamage, Timothy Lovelace, Jayma Meyers, Todd Pettys, Clarence Pollard, Gary Sailes, Joseph Yockey, and Larry Zelenak. Earlier drafts of this article were presented by the authors at the "Sports Project: 4th Global Meeting” held at Mansfield College, Oxford University in Oxford, United Kingdom, on Sept. 26, 2015, and at the Midwest Black Law Students Association Regional Convention in Indianapolis, Indiana, on Feb. 21, 2015. In addition, professor Kevin Brown delivered earlier versions of this article to the faculty of the University of Iowa College of Law on March 24, 2017, in Iowa City, Iowa; at the 66th Annual Meeting of the Seventh Circuit Bar Association and Judicial Conference of the Seventh Circuit May 2, 2017, held in Indianapolis, Indiana; at the "Sport: Probing the Boundaries" conference as part of the inaugural meeting of the International Association for the Interdisciplinary Study of Sport on Dec. 3, 2017, held in Vienna, Austria; and at the Annual Meeting of the Black Entertainment \& Sports Association held in Los Cabos, Mexico, on Nov. 8, 2018. We would like to thank the participants of the conferences for their helpful suggestions. We also would like to thank Elaena Harris and Ashanté Travis for their exceptional research assistance, and the Indiana University Maurer School of Law and the Indiana University School of Public Health for the financial support they provided for this article. 